\title{
Electroactive Smart Materials for Neural Tissue
}

\section{Regeneration}

Tiffany S. Pinho ${ }^{a, b, c}$, Cristiana B. Cunha ${ }^{c}$, Senentxu Lanceros-Méndez ${ }^{d, e f}{ }^{*}$, António J. Salgado $a, b$

${ }^{a}$ Life and Health Sciences Research Institute (ICVS), School of Medicine, University of Minho, Campus de Gualtar, 4710-057 Braga, Portugal.

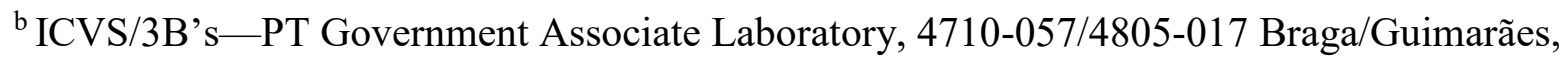
Portugal.

${ }^{c}$ Stemmatters, Biotecnologia e Medicina Regenerativa SA, 4805-017 Guimarães, Portugal.

${ }^{\mathrm{d}}$ Center of Physics, University of Minho, 4710-058 Braga, Portugal

${ }^{\mathrm{e}}$ BCMaterials, Basque Center for Materials, Applications and Nanostructures, UPV/EHU Science Park, 48940 Leioa, Spain.

${ }_{\mathrm{f}}^{\mathrm{f}}$ Ikerbasque, Basque Foundation for Science, 48009 Bilbao, Spain

Keywords: central nervous system, neural regeneration, electroactive smart materials, spinal cord injury, brain injury 
Abstract

Repair in the human nervous system is a complex and intertwined process which offers significant challenges to its study and comprehension. Taking advantage of the progress in fields such as tissue engineering and regenerative medicine, the scientific community has witnessed a strong increase of biomaterial-based approaches for neural tissue regenerative therapies. Electroactive materials, increasingly being used as sensors and actuators, also find application in neurosciences due to their ability to deliver electrical signals to the cells and tissues. The use of electrical signals for repairing impaired neural tissue presents therefore an interesting and innovative approach to bridge the gap between fundamental research and clinical applications in the next few years. In this review, first a general overview of electroactive materials, their historical origin and characteristics is presented. Then, a comprehensive view of the applications of electroactive smart materials for neural tissue regeneration is presented, with particular focus on the context of spinal cord injury and brain repair. Finally, the major challenges of the field are discussed and the main challenges for the near future presented. Overall, it is concluded that electroactive smart materials are playing an ever-increasing role in neural tissue regeneration, appearing as potentially valuable biomaterials for regenerative purposes. 


\section{Introduction}

The human central nervous system (CNS) - comprising primarily the brain and spinal cord - is a complex and intertwined network of millions of cells that control movements, senses, cognition and emotions ${ }^{1 .}$ Injuries to the CNS are diverse and widespread, including neurodegenerative diseases, neurodevelopmental diseases, and traumatic injuries, all largely contributing to morbidity and mortality in developed and developing countries. Despite extensive research, development of therapeutic interventions for CNS brings an important number of challenges, in part due to its unique physiological and anatomical features: the arrangement of the brain and cord inside bone structures such as the skull and vertebrae; the vascular system with selective permeability; and ultimately the limited capacity for self-repair, as opposed to the peripheral nervous system (PNS) ${ }^{2}$.

Few treatment options are available for patients with CNS injury, being the traditional therapeutic approaches mainly based on palliative care, where symptoms are managed without overcoming disease progression or promoting tissue regeneration. Therefore, and due to the limited ability of the CNS to spontaneously regenerate following traumatic injury or disease, patients often suffer from permanent functional damage and long-term disability, which poses further challenges for the development of therapeutic interventions ${ }^{3}$.

The critical need for regenerative medicine strategies and recent advances on our understanding of CNS regeneration and its challenges have markedly improved the availability of potential reparative strategies. Some of the most promising approaches rely on biomaterials, which have come a long way since their conventional use mainly as structural elements with defined properties. Nowadays, biomaterials have significantly changed the panorama of 
therapeutics for the nervous system. Biomaterials play a key role in providing a suitable environment for tissue regeneration, particularly by mimicking the extracellular matrix in supporting cellular growth and differentiation ${ }^{4}$. To further expand their applicability and foster their tissue regenerative capability, biomaterials are frequently combined with biological factors, cells or molecules ${ }^{5}$. Moreover, their tunable chemical and/or physical properties such as stiffness, mechanical strength, pore size and structural features have allowed the development of tailored systems, optimizing the interaction of biomaterials with cells and living tissues ${ }^{6}$. This understanding of biological systems and their interface with biomaterials has provided the opportunity to achieve relevant improvements, either through neuroregenerative or neuroprotective biomaterial-based approaches.

Naturally occurring or synthetic biomaterials have been developed to act as scaffolds, matrices or constructs ${ }^{7}$. Although the state of the art in biomaterials design has been evolving throughout the years, their ultimate goal remains the same: to interact with, or mimic, biological systems in order to restore, repair, maintain or replace damaged tissue or biological functions ${ }^{8}$. Based on their applications, biomaterials can be engineered in different forms from a great variety of primary products, such as ceramics, metals, polymers or even living cells and tissues 7 . Furthermore, to fulfill safety and health criteria, biomaterials should be non-toxic, nonimmunogenic and biocompatible ${ }^{9}$.

This review presents an overview of the use of a specific subset of biomaterials, electroactive polymers, for nervous system regenerative therapies. Starting from a brief historical perspective, this review introduces the main types of electroactive smart materials. Then, the main focus is set on reviewing the applications of these materials for neural tissue regeneration, including brain and nerve repair in the context of spinal cord injury. Finally, major challenges and concerns that 
remain in this field are presented and discussed, as well as future directions to follow in the upcoming times.

2. Electroactive smart polymers: an overview

It is generally considered that biomaterials for tissue regeneration applications should present as much similarities as possible with the existing tissue they are intended to interact. In fact, the extracellular matrix (ECM), as a highly dynamic structure constantly remodeling and interacting with cellular constituents, has an active role in processes such as tissue differentiation, morphogenesis and homeostasis ${ }^{10}$. However, and although advances in polymer science over the past decades have turned polymers into one of the most prevalent classes of materials used for tissue regeneration, most of the scaffolds being used remain non-responsive to external changes of the environment ${ }^{11,12}$. Therefore, the need for stimuli-responsive materials that interact with native tissues has been spurring the interest in a subset of electroresponsive polymers such as electroactive smart polymers. By definition, electroactive polymers are systems able to respond specifically to electrical fields, mainly either by delivering electrical signals or by shape or size variations, leading to stimulus/response behaviors ${ }^{13}$. The observed electrically-coupled response of these polymers to stimulus can be reversible or irreversible, ranging from the delivery of electrical signals, to changes in their polymeric structure or intrinsic properties upon the stimulus 14. In line with these unique characteristics, electroactive materials have also been referred to smart or intelligent materials in the literature.

The first documented report of electroactive material properties dates back to 1880 when Wilhelm Roentgen observed a difference in length of a fixed rubber band with a weight attached on one end when electrically charged and discharged ${ }^{15,16}$. Some years later, in 1899, Sacerdote extended Roentgen's experiment, confirming it, and conveyed the effect of the strain response to 
electric field activation ${ }^{16,17}$. In 1925 , the field further progressed with the fabrication of the first electroactive polymer, the electret, made by a subsequent cooling and solidification process of equal parts of Carnauba wax and resin, together with beeswax, under a direct current bias field 18,19. However, the interest in the field started to decrease gradually in the following years and it was only in 1969, with the discovery of piezoelectricity in poly-vinylidene fluoride (PVDF) by Kawai, that electroactive materials started to draw attention again in the research community ${ }^{20}$. In fact, this achievement launched research into PVDF-based materials but also into other polymer systems that would exhibit similar electroactive responses. Improvements in the latest years have shown the ability to form electroactive polymers into various shapes, with different flexibilities and higher strain capabilities making them a promising technology with a wide variety of applications, attracting scientists and engineers from different fields ${ }^{21 .}$

As biomaterials capable to respond to environmental changes, electroactive polymers can be categorized in several groups according to their electrical characteristics: dielectric polymers, ionic conductive polymers, intrinsically conductive polymers and electrically conductive polymer composites ${ }^{13,16}$. Actuation of dielectric polymers is driven by electrostatic forces, and includes electrostrictive, electrostatic, piezoelectric, and ferroelectric materials ${ }^{16}$. In contrast, ionic polymers, such as gels, involve mobility or diffusion of ions within the polymer, often requiring an electrolyte for the actuation mechanism ${ }^{22}$. Finally, intrinsically conductive polymers and polymer composites, increasingly used as biomaterials, are characterized by their electronic conductivity ${ }^{16 .}$

Although electroactive materials are most commonly applied to sensors and actuators ${ }^{16}$, extensive research and development efforts have been carried out to allow their successful 
application in a broad range of biomedical areas such as tissue engineering ${ }^{23,24}$, cell/drug delivery ${ }^{25}$ and microbiology ${ }^{26}$.

\subsection{Electroactive dielectric polymers}

Dieletric polymers are passive polymers with the ability to store electric energy when electrical fields are applied. These materials are full of charged particles that move once the material is stimulated with external electric fields providing the material with a charge storage capability ${ }^{27}$.

One of the representatives of dielectric polymers are piezoelectric materials, which are able to induce an electrical charge in response to an applied mechanical strain and vice-versa ${ }^{28,29 .}$ Since the discovery of piezoelectricity, back in 1880 by the Curie brothers ${ }^{30}$, research in the field of piezoelectric materials has enjoyed exciting and rapid developments, including the integration of these materials in biological systems. In fact, a real prospect for piezoelectric materials for neural tissue regeneration was created, particularly taking into account the importance of electrical charges for physiological neuronal activity ${ }^{31 .}$ Moreover, the non-invasive nature of the generated electrical charges, derived only from mechanical forces and not depending on the use of external power sources, also lead to another great advantage of piezoelectric materials ${ }^{31,32}$. Interestingly, piezoelectricity can be found in some mammalian tissues, particularly the ones containing $\alpha$ keratin, such as hair, or tissues rich in collagen, including cartilage, tendons and bone 29.

In the last decades, a variety of piezoelectric materials emerged, including inorganic, organic and hybrid alternatives. Inorganic piezoelectric materials, or piezoceramics, comprise lead zirconate titanate $(\mathrm{PZT})$, barium titanate $\left(\mathrm{BaTiO}_{3}\right)$, zinc oxide $(\mathrm{ZnO})$, aluminium nitride (AlN), lithium niobite $\left(\mathrm{LiNbO}_{3}\right)$ and quartz, among others. Their piezoelectricity can be explained by dipolar variations when the piezoelectric material is under stress ${ }^{29}$. Although piezoelectric 
ceramics present high piezoelectric coupling coefficients, the use of ceramics for tissue regeneration purposes might bring some constrains, mainly due to limited flexibility, fragility and the difficulty on preparing them in a variety of shapes ${ }^{33 .}$ To overcome these limitations, organic piezoelectric materials started to gain more relevance for tissue regeneration purposes. Piezoelectricity in organic materials occurs by re-orientation of the molecular dipoles inside the polymer, which includes synthetic polymers and natural biopolymers. Synthetic polymers include the widely investigated poly(vinylidene fluoride) (PVDF) and co-polymer approaches by conjugating with trifluoroethylene (PVDF-TrFE) or hexafluoropropylene (PVDF-HPF), among others; poly-L-lactic acid (PLLA); and poly-3-hydroxybutyrate-3-hydroxyvalerate (PHBV) 29,31,32,34. Additionally, natural biopolymers that exhibit piezoelectricity include cellulose, chitin, chitosan and collagen ${ }^{33,34 .}$ Together with high processing flexibility, piezoelectric polymers also have the ability to meet the biocompatibility and biodegradability criteria for products to be used in regenerative medicine, constituting a great advantage when compared with inorganic materials 34.

\subsection{Ionic conductive polymers}

To ensure successful tissue regeneration, biomaterials should fulfil several features, among which the ability to mimic the natural microenvironment of tissues at the site of implantation ${ }^{35}$. Although this issue remains one of the biggest challenges in the field, the development of hydrogel-based approaches appears as one attractive strategy to be pursued. Hydrogels based on ionic conductive polymers, which have their electrical conductivity due to the motion of ionic charge, are typically hybrid polymeric structures that usually combine two different polymers: an inherently conductive polymer and a non-conductive polymer. While the conductive polymer is responsible for the electrical conductivity, the non-conductive polymer, characterized by highly 
hydrated gel properties, provides in vitro and in vivo biocompatibility, structural support for cells and diffusion capacities of small molecules ${ }^{36}$. These attractive characteristics have opened up a whole new range of possibilities for hydrogel-based approaches, particularly for neural regeneration purposes, mainly based on their biocompatibility and their ability to incorporate distinct (nano)materials ${ }^{37}$.

\subsection{Intrinsically conductive polymers}

Intrinsically conductive polymers are another type of smart polymers with high conductivity and compatible with a vast array of biological molecules ${ }^{38,39}$. The mode of charge propagation in conductive polymers is based on the movement of ions into and from the polymer structure either through conjugated systems or between neighboring redox sites ${ }^{39,40}$. Conductive polymers offer a vast number of possibilities, mainly due to their versatility, easy and inexpensive synthesis and flexibility. In fact, these polymers allow fine-tuning of their electrical, physical or chemical properties to meet the specific needs of their application ${ }^{41 .}$

The first report of conductive polymers dates back to 1862, when Letheby synthesized polyaniline (PANI) trough anodic oxidation of aniline in dilute sulfuric acid, resulting in an insoluble blue pigment deposit on a platinum electrode ${ }^{42}$. Nevertheless, it was not until the end of the 1970s that the field was significantly launched, with the discovery and preparation of polyacetylene (PA) with increased conductivity after halogen doping ${ }^{43,44 . ~ I m p o r t a n t l y, ~ A l a n ~}$ J.Heeger, Alan G. MacDiarmid and Hideki Shirakawa were jointly awarded the Nobel Prize in Chemistry in 2000, "for the discovery and development of conductive polymers" 45.

A large effort has been made on the development of conductive polymers. Currently there are more than 25 conductive available polymer systems, which greatly expands their biomedical 
applications ${ }^{46}$. Although polypyrrole (PPy) has become by far one of the most studied and used conductive polymers, growing evidence in the literature also supports the use of PANI and poly (3,4-ethylenedioxythiophene (PEDOT), particularly for tissue regeneration purposes ${ }^{47}$.

\subsection{Electrically conductive polymer composites}

Together with the aforementioned conductive polymers, carbon nanomaterials, particularly carbon nanotubes and graphene, can be used to increase electrical conductivity of polymers, creating electrically conductive polymer composites. These carbon-based conductive fillers allow the formation of filler-polymer matrix interactions, which are responsible for an increase in conductivity while still maintaining the polymeric characteristics of the material, thus garnering a great deal of interest as innovative tools for tissue engineering applications ${ }^{48}$. Graphene is a two-dimensional material formed by single layers of carbon atoms connected through $\mathrm{sp}^{2}$ hybridization forming a honeycomb pattern ${ }^{49}$. Due to their electrical conductivity and capacity to be functionalized for improved biological capacities, graphene and particularly graphenebased nanocomposites have made significant contributions in neural regenerative medicine ${ }^{50-52}$. According to the number of layers, sheet dimensions and functionalization, graphene-based materials can be grouped in different categories, being single-layer graphene, graphene oxide (GO) and reduced graphene oxide (rGO) among the most commonly applied for regenerative purposes ${ }^{53}$. Together with two-dimensional materials, graphene sheets can also be rolled into hollow cylindrical tubular structures to originate carbon nanotubes (CNTs). Like graphene sheets, CNTs also present high electrical conductivity, strength, flexibility and the possibility for chemical functionalization, which results extremely useful for neural tissue regenerative purposes ${ }^{54,55}$ 
3. Electroactive materials for neural tissue regeneration

The CNS is affected by a vast array of different pathologies, that can be roughly divided in two classes, leading to divergent clinical issues: neurodegenerative diseases, such as Alzheimer's disease and Parkinson's disease, which consist in progressing and debilitating conditions that ultimately result in cellular degeneration and neuronal death; and injuries derived from an external trauma, such as spinal cord and traumatic brain injuries, where the neural tissues are physically damaged ${ }^{56,57 .}$

Preventing or treating the degenerative process, and ultimately neuronal loss, the central pathological outcome of a CNS injury, is still one of the biggest challenges facing neuroscientists today. It has long been considered that the adult CNS does not regenerate following injury, and although an initial growth response after injury might be observed, the fact is that adult central neurons fail to regrowth due to a multitude of factors, ranging from the inhibitory environment the axons encounter within the lesion, to the intrinsic inability of injured axons to regrow ${ }^{2}$. Therefore, an urgent need to develop more sophisticated and combinatorial treatment strategies for CNS injury arise, as no options are yet available to allow complete or near-complete tissue regeneration or replacement for recovery of function in the injured area.

In the next sections, various emerging electroactive-based approaches are described particularly regarding their biocompatibility, in vitro cell adhesion, proliferation and differentiation, molecular mechanisms underlying neural regeneration and effects in promoting functional and neurological recovery (Figure 1). 


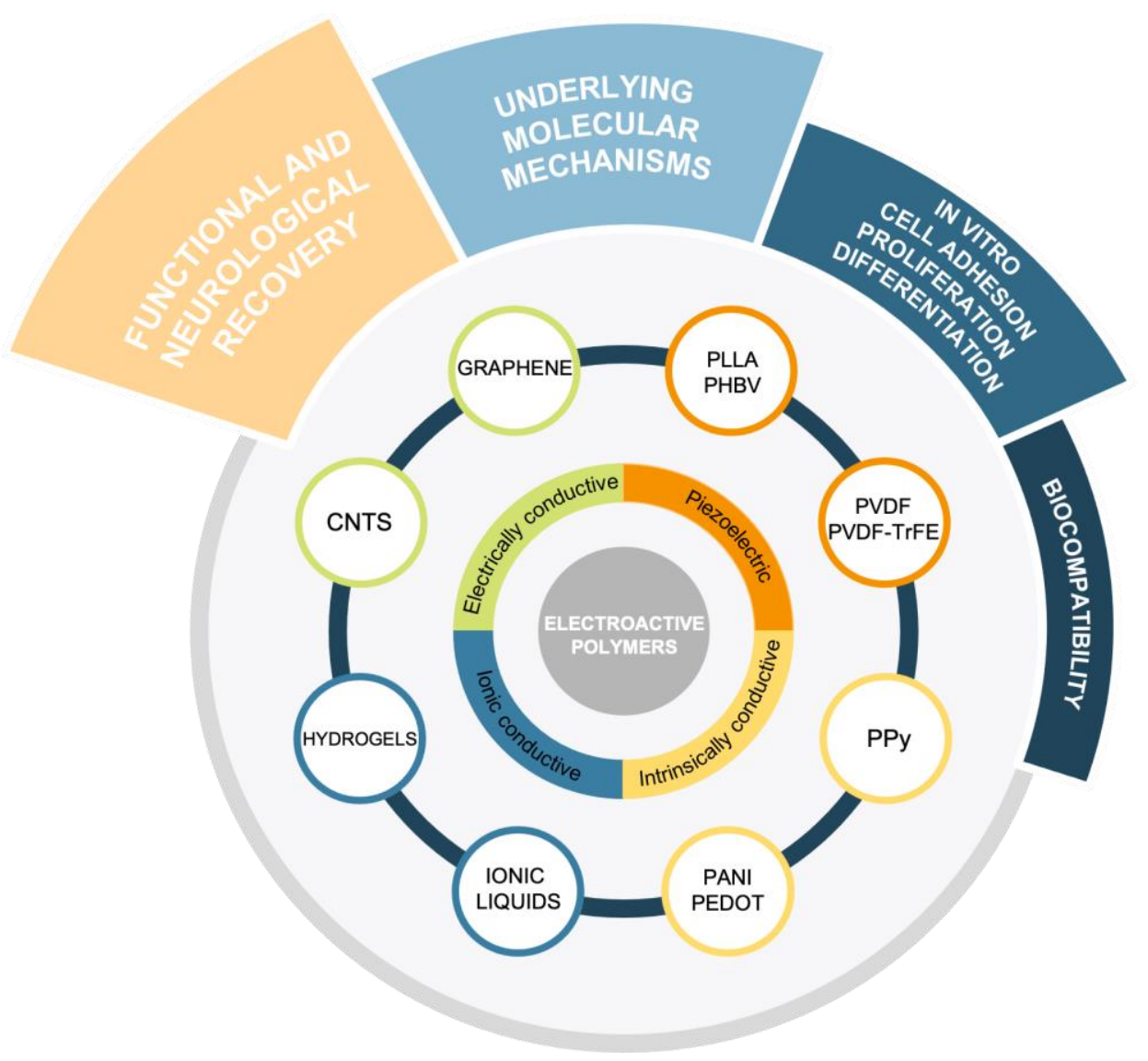

Figure 1. Schematic overview. Electroactive polymers can be subdivided according to their conduction mechanism into electronically conductive polymer composites, piezoelectric polymers, ionic conductive polymers and intrinsically conductive polymers. Overall, studies focusing on electroactive-based approaches for neural regeneration are devoted to the evaluation of the biocompatibility of the materials, in vitro and in vivo performance and underlying molecular mechanisms for neuroregeneration ${ }^{13,21,47,58}$. 


\subsection{Electroactive materials for neuronal outgrowth and differentiation (in vitro)}

The multipotentiality and self-renewing capabilities of stem cells have spurred an unprecedented interest and excitement over them in the past few decades. Since the acknowledgment that neural stem cells (NSCs) or multipotent neural progenitor cells continue to be generated throughout life, in the subventricular zone (SVZ) and the dentate gyrus of the hippocampus, growing interest in their therapeutic potential has been observed ${ }^{59-61 .}$ Considering their regenerative ability upon injuries and diseases, and the fact that they are able to primarily differentiate into neurons, astrocytes and oligodendrocytes, NSCs are suitable candidate cells for the cellular repair of lesions of the CNS, and therefore, regarded a key population to consider for neural tissue regenerative therapies ${ }^{62,63 .}$ Accordingly, several reports have been testing the behavior of NSCs, and other neuronal-like cells on scaffolds or interfacing electroactive materials in recent years (Table 1), unwrapping numerous possibilities and opportunities for regenerative therapeutic approaches.

\subsubsection{Electrically conductive materials}

Conductive polymers have been gathering attention for neural tissue regenerative applications due to their physical and chemical properties, but also because their polymeric features, such as processing flexibility. When combined with electrical stimulation, PPy containing the anionic dopant dodecylbenzenesulfonate (DBS) induced differentiation of NSCs towards neurons rather than glial cells, with neurons presenting highly branched long neurites when compared with unstimulated cultures ${ }^{64}$. Nonetheless, conductive polymers are not biodegradable, which could induce immune responses and adverse reactions. In order to by-pass this issue, conductive polymers have been combined with other biodegradable polymers with biologically relevant 
properties. For example, aligned PPy-PLLA fiber films could guide neuron-like rat phaeochromocytoma (PC12) cells outgrowth and their neurites extension along the direction of fiber axis which is further enhanced upon electrical stimulation ${ }^{65}$. Similarly, electrically stimulated PPy-PLLA fiber films coated with chitosan and poly(caprolactone) (PCL) also promoted neurite growth and alignment of PC12 cells, fostering the application of conductive polymer composites for neuroregeneration ${ }^{66}$. On a different approach, components of the ECM such as laminin, fibronectin and collagen have been used to significantly increase PC12 cell adhesion, neurite growth and length on conductive fiber-films of PLLA fibers and PPy nanoparticles ${ }^{67}$.

PEDOT, one of the most investigated polythiophene derivatives, has been demonstrated to provide appropriate cell growth environments for neural regeneration, mainly due to its high electrical conductivity and chemical stability ${ }^{68}$ When doped with polystyrene sulfonate (PEDOT-PSS), aqueous dispersion of PEDOT in solution is facilitated. Using fibrous scaffolds based on silk fibroin functionalized with PEDOT-PSS or dimethyl sulfoxide (DMSO)-treated PEDOT-PSS (optimized conductance), Magaz et al assessed the biological responses to these substrates on analogue NG108-15 neuronal cells. Results demonstrated that cells remained viable on all scaffolds groups while presenting better metabolic activity and proliferation when compared with neat silk. Moreover, scaffolds were able to support neurite sprouting during the differentiation phase ${ }^{69}$. By improving the functionality of PEDOT:PSS with incorporation of 3,4-ethylenedioxythiophene (EDOT) oligomers, Ritzau-Reid et al demonstrated that oligoEDOT-PCL is biocompatible and enhanced neurite length and branching of NSCs upon electrical stimulation, reinforcing the potential of polythiophene-based materials for neural tissue engineering 70 . 
In vitro studies have shown that graphene-based materials are biocompatible and induce biological responses from different tissues/cells. Indeed, graphene has been reported to promote neurite sprouting and outgrowth of mouse hippocampal cells ${ }^{71}$, astrocyte to neuron communication $^{72}$ and neuronal differentiation of human neural stem cells ${ }^{73,74}$. Moreover, taking advantage of electrophysiological recordings and calcium imaging, graphene was also described to enhance and support neuronal performance and electrical signaling in a functional neuronal network ${ }^{75}$. Nevertheless, the abovementioned studies were performed on planar two-dimensional (2D) graphene substrates, which fails to recapitulate the ECM structure and environment observed in an in vivo situation. To overcome these limitations, three-dimensional (3D) graphene-based materials have begun to be explored. Particularly, it was described that 3D graphene foams are able to support NSCs growth and proliferation, as well as enhance their neuronal and astrocytic differentiation, when compared with $2 \mathrm{D}$ graphene films ${ }^{76 .}$ On a different set of experiments, NSCs behavior on various stiffness of 3D graphene foams was investigated, revealing that a stiff scaffold has a better performance on NSCs adhesion, growth and differentiation toward astrocytes when compared to soft scaffolds, thus highlighting the important role of mechanotransduction to guide adhesion, proliferation, and differentiation of $\mathrm{NSCs}^{77}$.

Similar to graphene, CNTs have become a promising and useful platform for neural tissue regeneration mainly due to their electrical, structural and mechanical properties, but also because they can be further functionalized with chemical or biological relevant molecules. According to the number of layers of graphite, CNTs can be classified as single-walled CNTs (SWCNTs) and multi-walled CNTs (MWCNTs) ${ }^{78}$. MWCNTs modified by amino groups have been shown to be biocompatible and to promote nerve growth factor (NGF)-dependent outgrowth of neuronal 
neurites in dorsal root ganglion (DRG) neurons and of PC12 cells ${ }^{79}$. In fact, a recent study using 3D-printed MWCNTs functionalized with amine and incorporated with poly (ethylene glycol) diacrylate (PEGDA) scaffolds demonstrated enhanced NSCs growth on MWCNTs embedded scaffolds, as well as neuronal and oligodendroglial differentiation of NSCs upon electrical pulse stimulation, suggesting this scaffold as a promising candidate to promote neural differentiation 80. In a different approach, a fibrous scaffold comprising polyurethane (PU) and silk fibroin associated with functionalized MWCNTs was also evaluated for neuroregeneration, showing growth and proliferation of Schwann cells (S42), together with the differentiation and spontaneous neurite outgrowth of PC12 cells ${ }^{81}$. Using a combinatorial approach based on a scaffold composed of MWCNTs and poly(lactic-co-glycolic acid) (PLGA) together with electrical stimulation, Wang et al reported that, upon stimulation, PC12 cells and DRG neurons cultured on the scaffold presented enhanced neurite extension, together with increased cellular attachment, proliferation and myelin basic protein (MBP) expression on Schwann cells ${ }^{82}$. Similarly, combination of CNTs with positively charged poly(caprolactone fumarate) (PCLF) and [2-(methacryloyloxy)ethyl]trimethylammonium chloride (MTAC) also resulted in improved growth and differentiation of PC12 cells, together with enhanced neurite protrusions upon electrical stimulation ${ }^{83}$. Although a vast array of studies has been carried out on the effect of CNT-based scaffolds on the behavior of NSCs, a comprehensive picture of the molecular mechanisms underlying these interactions are yet not understood. To fulfill this goal, using a CNT-multilayered nanocomposite Shao et al demonstrated that, besides promoting cell adhesion, viability, differentiation, neurite outgrowth, and electrophysiological maturation of NSCsderived neurons, the interactions between this CNT-based composites and NSCs involved the integrin-mediated interactions mainly activating focal adhesion kinase (FAK). This subsequently 
initiates downstream signaling events that regulate neural cell survival, proliferation, differentiation, and synapse formation ${ }^{84}$.

\subsubsection{Piezoelectric polymers}

Piezoelectric scaffolds have been increasingly employed for tissue engineering purposes, once they enable electrical stimulation without the need of an external power source ${ }^{24}$ PVDF films were shown to support and enhance neurite growth and branching of rat spinal cord neurons ${ }^{85}$, while PVDF-TrFE promoted neuronal differentiation of hNSCs and neurite extension of DRG neurons ${ }^{86,87}$. Moreover, PVDF-TrFE films containing $\mathrm{BaTiO}_{3}$ nanoparticles promoted viability and differentiation of human neuroblastoma SH-SY5Y cells, together with ultrasound mediated cell adhesion, differentiation and increased neurite length of cells seeded on the scaffolds ${ }^{88}$. Similarly, ultrasonically stimulated poled $\beta$-PVDF membranes also led to increased neurite generation in PC12 cells, with comparable efficiency to commonly used NGF protocols ${ }^{89 .}$ It is well known the importance of oriented growth of neural cells and neurites for recovering of nerve functions. In fact, extensive progress on bio-fabrication technologies has brought to light techniques such as electrospinning to create contact-guidance fibrous matrices which have been successfully applied for the growth of neural networks. One such example are PLLA nanofibrous scaffolds, which have been shown to promote the differentiation of PC12 cells ${ }^{90,}$ guide the neurite outgrowth of SH-SY5Y cells ${ }^{91}$, guide neurite outgrowth of DRGs and Schwann cell migration along the aligned fibers ${ }^{92,93}$ and promote cell adhesion, growth, proliferation and directed-neurite outgrowth of mouse induced pluripotent stem cells (iPSCs)-derived NSCs (iNSCs) 94. Furthermore, in order to improve biocompatibility, processability and biological effects, the surface modification of nanofibrous scaffolds has been considered. Aligned PLLA nanofibrous scaffolds coated with GO have been reported to promote rat Schwann cells 
proliferation, as well as proliferation, differentiation and NGF-dependent neurite growth of PC12 cells ${ }^{95}$.

\subsubsection{Ionic conductive polymers}

A number of in vitro studies using PC12 cells demonstrated that conductive hydrogels, either based on PEDOT ${ }^{96}$, carbon nanotubes ${ }^{97-100}$ or graphite nanofilaments ${ }^{101}$ are able to support cell adhesion, viability and proliferation, without cytotoxicity. In a step further, reports using conductive hydrogels based on PANI ${ }^{102,}$ PEDOT ${ }^{103,104,}$ CNTs/PPy ${ }^{105}$ have also demonstrated NSCs adhesion and differentiation, mainly towards neurons and astrocytes. In a different set of experiments, a bioprinting system consisting of a 3D printed conductive hydrogels using PEDOT:polystyrene sulfonate (PSS) solution, was used in combination with electrical stimulation to evaluate neuronal differentiation. Results have demonstrated the effectiveness of the fabricated material by the evaluation of neuronal differentiation capacity upon stimulation of encapsulated DRG neuronal cells ${ }^{106}$.

Table 1 Summary of electroactive materials that promote in vitro neuronal outgrowth and differentiation

\begin{tabular}{|c|c|c|c|c|}
\hline Category & $\begin{array}{l}\text { Type of } \\
\text { electroactive } \\
\text { material }\end{array}$ & $\begin{array}{l}\text { Biological } \\
\text { System }\end{array}$ & Outcomes & Authors (years) \\
\hline \multirow{2}{*}{$\begin{array}{l}\text { Conductive } \\
\text { polymers }\end{array}$} & $\mathrm{PPy}^{\mathrm{a})}(\mathrm{DBS})^{\mathrm{b})}$ & $\mathrm{NSCs}^{\mathrm{c}}$ & $\begin{array}{lr}\begin{array}{l}\text { Differentiation } \\
\text { neurons, into } \\
\text { branched and long } \\
\text { neurites }\end{array} & \end{array}$ & $\begin{array}{l}\text { Stewart et al }{ }^{64} \\
\text { (2015) }\end{array}$ \\
\hline & PPy-PLLA ${ }^{\mathrm{d})}$ & $\mathrm{PC} 12^{\mathrm{e})}$ & $\begin{array}{l}\text { Guidance of outgrowth } \\
\text { and neurite extension }\end{array}$ & $\begin{array}{l}\text { Zou et al }{ }^{65} \\
\text { (2016) }\end{array}$ \\
\hline
\end{tabular}




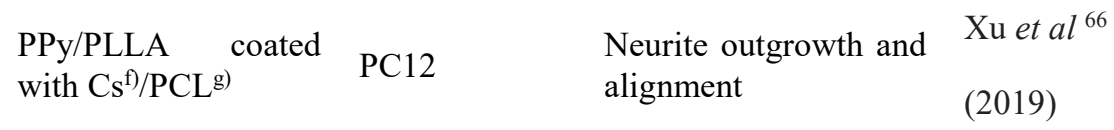

PLLA fibers/PPy nanoparticles coated with laminin,

PC12

fibronectin, collagen

Cell adhesion, neurite Zhou et al 67

PEDOT $^{\text {h) }}{ }^{\text {PSS }}{ }^{\text {i) }}$

DMSO'j)_PEDOT-

PSS

NG108-15

Increased metabolic activity, neural sprouting (2017)

OligoEDOT $^{\mathrm{l})-\mathrm{PCL}} \quad \mathrm{iNSCs}^{\mathrm{m})} \quad \begin{aligned} & \begin{array}{l}\text { Biocompatibility, } \\ \text { proliferation } \\ \text { differentiation. }\end{array} \\ & \text { Ond }\end{aligned}$ and Ritzau-Reid $^{70}$

Graphene-based materials

$\begin{array}{llll}\text { Graphene films } & \begin{array}{l}\text { Mouse } \\ \text { hippocampal } \\ \text { cells }\end{array} & \begin{array}{l}\text { Biocompatibility, } \\ \text { neurite sprouting and } \\ \text { outgrowth }\end{array} & \text { Li } \text { et }^{71}\end{array}$

Biocompatibility, adhesion, proliferation and differentiation towards neurons and Park et al 73 Laminin-coated graphene films

NSCs

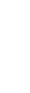 \\ (1)}

$\mathrm{rGO}^{\mathrm{n})}$ microfibers $\quad \mathrm{NSCs}$

ב

3D-graphene foams NSCs
towards neur
astrocytes

Adhesion, proliferation, differentiation intro neurons
Adhesion, proliferation, differentiation towards astrocytes and neurons
Li et al ${ }^{107}$
(2013)

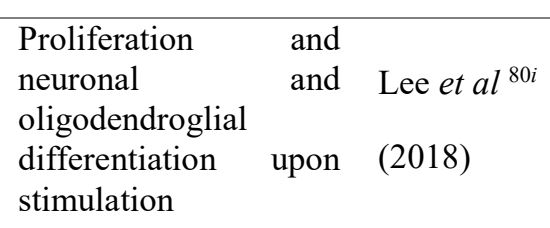

\section{Carbon} Nanotubes

\section{(CNTs)}

PUP)/Silk-MWCNTs $\quad$ S42 $^{\mathrm{q})}$; PC12




\begin{tabular}{|c|c|c|c|c|}
\hline $\mathrm{PLGA}^{\mathrm{r} / \mathrm{MWCNTs}}$ & $\begin{array}{l}\text { PC12; DRGs); } \\
\text { Schwann cells }\end{array}$ & $\begin{array}{l}\text { Neurite } \\
\text { attachment } \\
\text { proliferation }\end{array}$ & $\begin{array}{r}\text { extension; } \\
\text { and }\end{array}$ & $\begin{array}{l}\text { Wang et al } \\
\text { (2018) }\end{array}$ \\
\hline $\begin{array}{l}\text { PCLF-Graphene- } \\
\text { CNT-MTAC }^{t}\end{array}$ & $\mathrm{PC} 12$ & $\begin{array}{l}\text { Cell growth } \\
\text { extension, } \\
\text { proliferation }\end{array}$ & $h$, neurite & $\begin{array}{l}\text { Sun et al }{ }^{83 l} \\
(2020)\end{array}$ \\
\hline
\end{tabular}

\begin{tabular}{|c|c|c|c|c|}
\hline & $\left.\mathrm{PVDF}^{\mathrm{u}}\right)$ & $\begin{array}{l}\text { Rat spinal } \\
\text { cord neurons }\end{array}$ & $\begin{array}{l}\text { Neurite extension and } \\
\text { branching }\end{array}$ & $\begin{array}{l}\text { Royo-Gascon et } \\
\text { al }^{85} \\
(2013)\end{array}$ \\
\hline & PVDF-TrFE ${ }^{v)}$ & NSCs & $\begin{array}{l}\text { Neuronal } \\
\text { differentiation }\end{array}$ & $\begin{array}{l}\text { Lee } \text { et }^{a l}{ }^{86} \\
\text { (2012) }\end{array}$ \\
\hline & PVDF-TrFE & DRG & Neurite outgrowth & $\begin{array}{l}\text { Lee et al }{ }^{87} \\
\text { (2011) }\end{array}$ \\
\hline & $\begin{array}{l}\text { PVDF-TrFE/ } \\
\mathrm{BaTiO}_{3}{ }^{\mathrm{w})}\end{array}$ & SH-SY5Yx) & $\begin{array}{l}\text { Ultrasound-mediated } \\
\text { differentiation and } \\
\text { neurite growth }\end{array}$ & $\begin{array}{l}\text { Genchi } \text { et }_{\text {al }}{ }^{88} \\
\text { (2016) }\end{array}$ \\
\hline \multirow[t]{5}{*}{$\begin{array}{l}\text { Piezoelectric } \\
\text { scaffolds }\end{array}$} & PVDF & PC12 cells & $\begin{array}{l}\text { Ultrasound-mediated } \\
\text { neurite outgrowth }\end{array}$ & $\begin{array}{l}\text { Hoop et al }{ }^{89} \\
\text { (2017) }\end{array}$ \\
\hline & PLLA & PC12 & $\begin{array}{l}\text { Adhesion and } \\
\text { differentiation }\end{array}$ & $\begin{array}{l}\text { Yu et al }{ }^{90} \\
(2015)\end{array}$ \\
\hline & PLLA & SH-SY5Y & $\begin{array}{l}\text { Viability, } \\
\text { proliferation, guidance } \\
\text { of neurite outgrowth, } \\
\text { promote glucose and } \\
\text { lactic acid metabolism }\end{array}$ & $\begin{array}{l}\text { Yu et al }{ }^{91} \\
(2016)\end{array}$ \\
\hline & PLLA & $\begin{array}{l}\text { Chick DRG; } \\
\text { rat Schwann } \\
\text { cells }\end{array}$ & $\begin{array}{l}\text { Guidance of neurite } \\
\text { and Schwann cell } \\
\text { growth along the } \\
\text { aligned fibers }\end{array}$ & $\begin{array}{l}\text { Wang et al } 92,93 \\
\text { (2009) }\end{array}$ \\
\hline & PLLA & iNSCs & $\begin{array}{lr}\text { Adhesion, } & \text { growth, } \\
\text { proliferation } & \text { and } \\
\text { guidance of neurite } \\
\text { outgrowth }\end{array}$ & $\begin{array}{l}\text { Lin et } a l^{94} \\
(2018)\end{array}$ \\
\hline
\end{tabular}




\begin{tabular}{|c|c|c|c|c|}
\hline & GO-coated PLLA & $\begin{array}{l}\text { PC12; } \\
\text { Schwann cells }\end{array}$ & $\begin{array}{ll}\text { Proliferation, } & \text { NGF- } \\
\text { dependent } \\
\text { differentiation; } \\
\text { proliferation }\end{array}$ & $\begin{array}{l}\text { Zhang et al }{ }^{95} \\
\text { (2016) }\end{array}$ \\
\hline \multirow{7}{*}{$\begin{array}{l}\text { Conductive } \\
\text { Hydrogels }\end{array}$} & $\begin{array}{l}\text { rGOa-CNTpega- } \\
\text { OPFy) }^{\text {y }}\end{array}$ & PC12 cells & $\begin{array}{l}\text { Biocompatibility, } \\
\text { proliferation, } \\
\text { spreading and } \\
\text { stimulated neurite } \\
\text { development }\end{array}$ & $\begin{array}{l}\text { Liu et al 99,100a } \\
\text { (2016) }\end{array}$ \\
\hline & $\begin{array}{ll}\text { CAGNFs }^{\mathrm{z})} & \text { on } \\
\text { alginate } & \end{array}$ & PC12 cells & $\begin{array}{l}\text { Biocompatibility, } \\
\text { proliferation and } \\
\text { differentiation }\end{array}$ & $\begin{array}{l}\text { Homaeigohara } \\
\text { et al }{ }^{101 b} \\
(2019)\end{array}$ \\
\hline & PEDOT/CMCS & PC12 cells & $\begin{array}{l}\text { Biocompatibility, } \\
\text { adhesion, viability and } \\
\text { proliferation }\end{array}$ & $\begin{array}{l}\text { Xu et al }{ }^{96 c} \\
\text { (2018) }\end{array}$ \\
\hline & $\mathrm{Ch} / \mathrm{CNT}^{\mathrm{bb})}$ & $\begin{array}{l}\text { PC12 cells } \\
\text { and RSC96 } \\
\text { cells }\end{array}$ & $\begin{array}{l}\text { Biocompatibility, } \\
\text { proliferation } \\
\text { neuronal cells and } \\
\text { Schwann cells }\end{array}$ & $\begin{array}{l}\text { Wu et al }{ }^{97 d} \\
\text { (2017) }\end{array}$ \\
\hline & PVV $^{\mathrm{dd})}$-PANI & NSCs & $\begin{array}{l}\text { Adhesion, } \\
\text { proliferation, and } \\
\text { induction of neural } \\
\text { and } \\
\text { differentiation vlial } \\
\text { electrical stimulation }\end{array}$ & $\begin{array}{l}\text { Xu et al }{ }^{102 e} \\
\text { (2016) }\end{array}$ \\
\hline & $\begin{array}{l}\text { PEDOT-HA }{ }^{\text {ee) }} \text { into } \\
\text { Cs/Gel matrix }\end{array}$ & NSCs & $\begin{array}{lr}\text { Proliferation } & \text { and } \\
\text { differentiation into } & \text { int } \\
\text { neurons and astrocytes }\end{array}$ & $\begin{array}{l}\text { Wang } \\
\text { et al }^{103,104 f} \\
(2017 / 2018)\end{array}$ \\
\hline & $\begin{array}{lrr}\text { HA } & \text { incorporated } \\
\text { with } & \text { CNTs } & \text { and/or } \\
\text { PPy } & & \end{array}$ & $\begin{array}{l}\text { hfNSCs } \\
\text { hiPSC-NPCs }^{\text {ff) }}\end{array}$ & $\begin{array}{l}\text { Neuronal } \\
\text { differentiation, } \\
\text { improved } \\
\text { electrophysiological } \\
\text { functionality }\end{array}$ & $\begin{array}{l}\text { Shin et al }{ }^{105 g} \\
(2017)\end{array}$ \\
\hline
\end{tabular}

a) Polypyrrole (PPy); ${ }^{\text {b) }}$ dodecylbenzenesulfonate (DBS); ${ }^{c}$ neural stem cells (NSCs); ${ }^{\text {d) }}$ poly-Llactic acid (PLLA); e) neuron-like rat phaeochromocytoma (PC12) cells; f) chitosan (Cs); g) poly(caprolactone) (PCL); h) poly(3,4- ethylenedioxythiophene) (PEDOT); i) polystyrene sulfonate (PSS); j) dimethyl sulfoxide (DMSO); ${ }^{\mathrm{k}}$ ) analogue neuronal cells (NG108-15); ${ }^{1}$ oligomers of 4-ethylenedioxythiophene (EDOT); ${ }^{\text {m) }}$ induced pluripotent stem cells-derived neural stem cells (iNSCs); n) reduced graphene oxide (rGO); o) multi-walled carbon nanotubes (MWCNTs), poly (ethylene glycol) diacrylate (PEGDA); ${ }^{\mathrm{p})}$ polyurethane (PU); ${ }^{\text {) }}$ s42 Schwann 
cells; ${ }^{\text {r) }}$ poly(lactic-co-glycolic acid) $(\mathrm{PLGA}) ;{ }^{\text {s) }}$ dorsal root ganglion (DRG); ${ }^{\mathrm{t}}$ poly (caprolactone fumarate) (PCLF), [2-(methacryloyloxy)ethyl]trimethylammonium chloride (MTAC); u) polyvinylidene fluoride (PVDF); ${ }^{v}$ polyvinylidene fluoride trifluoroethylene (PVDF-TrFE); ${ }^{\text {w) }}$ barium titante $\left(\mathrm{BaTiO}_{3}\right) ;{ }^{\mathrm{x})}$ neuroblastoma cell line (SY-SY5Y); ${ }^{\mathrm{y}}$ ) reduced graphene oxide acrylate (GOa) sheets and carbon nanotube poly(ethylene glycol) acrylate (CNTpega) crosslinked with oligo(polyethylene glycol fumarate) (OPF) hydrogel (rGOa-CNTpega-OPF); ${ }^{\text {z) }}$ citric acid functionalized graphite nanofilaments (CAGNFs); aa) carboxymethyl chitosan (CMCS); ${ }^{\text {bb) }}$ chitin/carbon nanotube $(\mathrm{Ch} / \mathrm{CNT})$; ${ }^{\mathrm{cc})}$ Schwann cell (RSC96); dd) multifunctional high-strength hydrogels (termed PVV); ${ }^{\text {ee) }}$ hyaluronic acid (HA), chitosan/gelatin (Cs/Gel); ff) human fetal neural stem cells (hfNSCs), human induced pluripotent stem cell-derived neural progenitor cells (hiPSC-NPCs).

Despite the ever-increasing number of reports on the in vitro capabilities of electroactive smart materials to promote neuronal growth and differentiation, there is still a lack of studies addressing which are the underlying molecular mechanisms. The vast majority of electroactive materials proposed are composed of polymeric structures and therefore benefit from some polymer features useful for tissue regenerative purposes, such as chemical modifications and tunable properties of synthetic polymers, as well as extracellular matrix-like mimetics in the case of natural polymers. Although the literature existent does not explore the dual role of polymeric electroactive materials on cell interactions, on one hand as matrix polymeric materials and on the other as stimulus-generators, it is reasonable to consider that at least part of the effects observed might also be due to the polymeric nature of the material. In fact, a wide variety of polymeric structures have thoroughly been applied for regenerative tissue applications in the latest years ${ }^{108}$. However, the effect of electrical cues and electrical stimulation on cell migration, proliferation and differentiation is well known ${ }^{109}$, therefore the impact of electrical cues on neuronal behavior should also be considered.

Cellular differentiation is, in fact, an intricate and complex process mediated by a variety of factors, either intrinsic, such as epigenetic mechanisms and the dynamic interplay between the genome, or as the result of extrinsic signals provided by the microenvironment surrounding the 
cells. In fact, for the electroactive materials to have an effect on the cell, the physical cue sensed in the environment by the cell must be transduced into a molecular signal, and although the molecular mechanisms involved in cell differentiation are somehow described, the effect of electroactive materials on these processes is still unknown. Therefore, therapeutic approaches with electroactive materials, as strategies able to promote regeneration and growth, require a profound knowledge about their biological performance and the molecular mechanisms underlying their effects.

Although the vast majority of reports on the biological effects of electroactive materials do not mention the underlying molecular mechanisms, one study addressing PC12 differentiation by ultrasound stimulated $\beta$-PVDF, investigated the molecular mechanism behind it using biochemical inhibitors targeting different pathways. PC12 differentiation is described to be mediated by MAPK/ERK (mitogen-activated protein kinases/extracellular signal-regulated kinases) pathway, in the presence of NGF, and the cAMP (cyclic adenosine monophosphate) dependent pathway, which can be triggered by extracellular stimuli such as intracellular calcium concentration ${ }^{110 .}$ In order to understand which pathway could be playing a role in PVDFinduced differentiation, PC12 cells were treated with different inhibitors: K252a, which blocks TrkA receptor, where NGF molecules bind; roscovitine (RV), a blocker of p35/cyclin dependent kinase (Cdk5), a downstream effector of the MAPK/ERK pathway; and lanthanum chloride $\left(\mathrm{LaCl}_{3}\right)$, a calcium channel blocker. Results have shown a significant reduction of neurite outgrowth when using the calcium channel blocker $\mathrm{LaCl}_{3}$, suggesting that differentiation of PC12 cells on piezoelectric $\beta$-PVDF causes the activation of calcium channels, and that calcium influx plays a significant role in this process. Furthermore, the independent action of NGF and 
piezoelectric stimuli was also confirmed, once inhibitors of the NGF-triggered differentiation pathway did not influence $\beta$-PVDF stimulation and vice versa ${ }^{89}$.

In a different set of experiments, CNTs were shown to stimulate neurite outgrowth of DRG neurons by activation of the ERK signaling pathway independent of the phosphatidylinositol 3kinase (PI3K)/Akt signaling pathway. Even with MAPK/ERK kinase (MEK) inhibitor U0126, phosphorylated ERK was induced by CNTs, which suggests that this activation could occur through alternative signaling pathways than the Ras/Raf/MEK cascade ${ }^{111 .}$ Although this data should be interpreted with cautions, taking into account the indirect nature of inhibitor studies, results have shown that in fact, CNTs can promote neurite outgrowth of NGF-treated neurons through phospholipase C (PLC) signaling pathway, activating ERK independent of Ras/Raf/MEK cascade ${ }^{112}$.

Neuronal activity, including cellular growth, communication, differentiation and survival, is greatly dependent on endogenous electrical cues. In fact, an intrinsic property of neurons is their ability to respond to internal and external stimuli. Although electrical stimulation has been increasingly applied for neural regeneration, it remains under study how electrical stimulation exerts its effects at the molecular level. Several signaling pathways might be implicated in mediating the effect of electrical activity on neurons, such as PI3K/AKT, MEK/ERK, and calcium related mechanisms ${ }^{113,114 .}$ Electroactive materials certainly have a different effect on the tissues when compared with electrical stimulation, however the pathways underlying their effects might be similar. Thus, the molecular mechanisms underlying the cellular response to electrical stimulation might be useful candidates as a starting point when investigating the signaling pathways involved in electroactive materials-induced neuronal growth and differentiation. 
Overall, electroactive materials do show promise in fulfilling a role for use as regenerative materials, however, reports with these materials must address the molecular pathways behind those capabilities in order to allow these approaches to move to human clinical trials in the near future.

\subsection{Electroactive materials for neuroregeneration in the context of spinal cord injury}

Traumatic spinal cord injury (SCI) is a neurological disorder that causes permanent or temporary loss of motor and sensory function due to an external trauma to the cord, affecting thousands of individuals per year ${ }^{115 .}$ Lack of an available cure has placed SCI as a significant burden globally, with wide-ranging physical, emotional, social and economic consequences for patients, families and society. Despite knowing that the extent of trauma is dependent on the severity and anatomical placement of the lesion, a complex and distinctive pathophysiology occurs immediately following the initial injury suffered upon the mechanical impact ${ }^{116 .}$ In fact, $\mathrm{SCI}$ is an ongoing process, characterized by a cascade of secondary and deleterious events such as neuroinflammation, opening of the blood-brain or blood-spinal cord barrier, ischemia, excitotoxicity, and increased oxidative stress, among others ${ }^{116,117}$. The progression of injury further exacerbates cell death, propagating an inhibitory environment for regeneration, that leads to demyelination, formation of an astrocytic glial scar and ultimately neuronal death, resulting in continued and prolonged dysfunction and degeneration ${ }^{118 .}$

The permanent disability after SCI is associated with failure of axon regeneration and the disruption of neural circuits and connectivity. Therefore, functional recovery highly depends on enhancing neuroplasticity to foster the growth of injured and spared axons, to increase the 
strength of the connections still available and to stimulate de novo formation of circuits and connections ${ }^{119 .}$ To address neuroplasticity, different neuro-rehabilitative, neuro-chemical and electrical stimulation approaches have been considered and evaluated in preclinical and clinical studies. However, very few succeeded at showing some effects on axonal regeneration ${ }^{119,120 .}$ By mimicking both mechanical and electrical signature of the native spinal cord, electroactive materials could offer promising avenues to promote neuronal regeneration and re-establish axonal pathways in order to restore neurological function in SCI.

Electroactive scaffold-based approaches, mainly due to their effects on supporting and guiding regeneration of neural tissue at the injury, have been increasingly applied in the context of SCI 121.

A recent study using a conductive 3D nanofibrous scaffold with core-sheath structure containing a blend of conductive and biocompatible polymers (PLGA, PCL and PANI) demonstrated that, although the conductive scaffolds did not show any significant toxicity or negative effect on tissue regeneration, those conductive scaffolds had low ability in locomotor recovery when compared with non-conductive ones ${ }^{122 .}$ Taking into account the complexity underlying the pathophysiology of SCI, combinatorial strategies are expected to be more effective for maximizing the effect of treatment of SCI ${ }^{123}$. In fact, studies combining scaffoldbased approaches with biomolecular or cell therapy have been developed. As an example, combining methylprednisolone (MP), a glucocorticoid used for the management of SCI, with a nanofiber hybrid scaffold composed of PCL/polysialic acid (PSA) resulted on the suppression of tissue acute inflammation and apoptosis, mainly through decreased tumor necrosis factor- $\alpha$ (TNF- $\alpha$ ) and interleukin-6 (IL-6) release due to inhibition of microglia/macrophage activation and reduction of caspase-3 protein expression. Moreover, the scaffold also led to a reduction of 
glial scar formation and improved axonal regeneration, which resulted in a better functional recovery outcome ${ }^{124}$. Besides pharmacological approaches, combining growth factors closely related to nerve regeneration could also have a great potential for SCI applications. In fact, combination of insulin-like growth factor 1 (IGF-1) and brain-derived neurotrophic factor (BDNF) with GO-incorporated PLGA (PLGA/GO) electrospun nanofibers promoted NSCs proliferation and neuronal differentiation in vitro together with improved functional locomotor recovery, reduced cystic cavity and increased number of neurons at the injury site ${ }^{125}$. Interestingly, in the absence of functionalization with growth factors, rGO scaffolds also led to a pro-angiogenic and pro-regenerative scenario in the injured spinal cord, further encouraging investigation with graphene-based materials ${ }^{126,127}$.

On a different perspective, combination of 3D electrospun PLGA/polyethylene glycol (PLGAPEG) nanofiber scaffolds with iNSCs on a gelatin sponge, filled the lesion cavity and allowed iNSCs long-term survival and differentiation into neurons and glial cells within the 3D scaffolds in vivo. Moreover, the cell-seeded scaffold was also able to promote functional recovery of the spinal cord ${ }^{128 .}$ Similarly, using nanofibrous PCL scaffolds containing iNSCs together with activated Schwann cells, also promoted tissue remodeling and motor function recovery in a SCI model ${ }^{129}$, suggesting a positive role for combinatorial approaches of conductive scaffolds with NSCs for SCI therapeutics.

In order to re-establish communication across the injury, Lee et al developed fibrous piezoelectric PVDF-TrFE conduits with Schwann cells to bridge the completely transected adult rat spinal cord. Results have shown that the conduits are a suitable milieu for Schwann cells adhesion and proliferation, and most importantly supported regeneration of sensory and brainstem axons across the aligned fibers of the conduit, together with extension of 
astrocyte/glial fibrillary acidic protein $(\mathrm{GFAP})^{+}$processes and blood vessel formation 130. However, no behavioral assessments were performed once the animals were only evaluated for 3 weeks to examine early repair. Multi-channel nerve conduits also present an important role in guiding axonal growth and functional recovery after SCI. Sun et al fabricated two PLLA multichannel conduits, one with ladder-like porous channel wall (LNCs) and the other with nanofibrous channel wall (NNCs), in order to evaluate lesion-induced biological responses into a complete spinal cord transected injury rat model. The implantation of both conduits, but especially NNCs, alleviated inflammation and the accumulation of astrocyte/collagen scar, and, importantly, promoted the recruitment of endogenous NSCs and orientation control of axonal growth on the scaffolds. Furthermore, the denser micro-/nano-structured walls of the channel walls also allowed the confinement of the nerve fiber extension within the channels playing an important role in modulating the observed biological responses ${ }^{131 .}$

Conductive hydrogels have also been excellent candidates for SCI regeneration, mainly due to their ability to mimic both the 3D soft mechanical signature and electrical transmission function of the native spinal cord. A recent study by Zhou et al demonstrated the therapeutic efficacy after SCI of a highly conductive and biocompatible conductive polymer hydrogel based on tannic acid (TA), a plant-derived polyphenol, and conductive PPy polymer. Results in vitro have shown differentiation of NSCs into neurons while suppressing the development of astrocytes. In a SCI hemisection mice model implanted with the hydrogel, authors described an activation of endogenous NSCs neurogenesis in the lesion area, resulting in significant motor recovery. The possible mechanism behind the new endogenous neurogenesis observed could be explained by the endogenous electrical transmission properties of the material which is able to restore the interrupted spinal circuit in the area of the lesion ${ }^{132}$. 
Taking into consideration the limited treatment options for SCI, electroactive materials are a particularly promising therapeutic strategy. Studies have demonstrated that electroactive materials have proven to mitigate the inflammatory response that is commonly observed on SCI, reduce glial scar tissue formation, leading to better functional recovery outcomes. Although combinatorial strategies with scaffold-based approaches and biomolecular or cellular components have demonstrated the best results, the use of electroactive materials per se should not be discouraged. In fact, several non-smart biomaterials have demonstrated promising outcomes in preclinical animal studies, further encouraging the research into biomaterials for regenerative purposes ${ }^{133}$. Considering the complexity underlying the pathophysiology of SCI, mechanisms involved in the favorable outcomes observed are yet to be unveiled. Moreover, the multifactorial nature of combinatorial approaches should also be taken into consideration when looking for the mechanistic processes behind the therapeutic effects observed. Breaking it down into the different parts that compose the biomaterial is definitely the best approach to look into the underlying mechanisms involved. Overall, electroactive biomaterials are able to fill the lesion cavity and create a pro-regenerative environment, either through cellular or soluble molecules incorporation, and support and guide axonal growth and plasticity, mainly achieved due to their capacity of electrical-stimulus generators.

\subsection{Electroactive materials for brain repair}

Brain injury can be acquired in several and distinct ways, ranging from neurodegenerative conditions, vascular processes such as stroke, or acute lesions such as traumatic brain injury, to name a few ${ }^{134 .}$ Compromise or injury of the brain is, obviously, associated with a dramatic 
impact on survival, function and overall health. Additionally, few therapeutic approaches are presently available to achieve functional recovery, worsening the outcomes of such devastating conditions.

Neurodegenerative disorders are a wide-ranging class of debilitating conditions that result in progressive loss of disease-specific neural population and they include Alzheimer's disease (AD) and Parkinson's disease (PD), among others ${ }^{135}$. Increased prevalence of these disorders, owing in part to increased lifespan over the years, has become a great problem worldwide. Therapeutic strategies available nowadays are mainly symptomatic treatments, and therefore regenerative approaches are still lacking. Biomaterials have been trying to fill that void, being considered interesting and potential approaches in this field ${ }^{136 .}$ Using trimethyltin chloride (TMT)-induced rat neurodegeneration model, a recent study co-engrafted CNTs and NSCs isolated from human olfactory bulb and demonstrated that the injected composite restored cognitive deficits and neurodegenerative alterations associated with the rat model ${ }^{137}$. The mechanism by which this composite induced positive effects on cognitive and histological features is not completely understood. The authors suggest that implanted NSCs can migrate into the damaged areas and via cell replacement, integration and neuroprotective mechanisms promote repair and restoration of the deficits observed.

Parkinson's disease (PD) is characterized by the progressive degeneration of dopaminergic neurons in the substantia nigra pars compacta ( $\mathrm{SNpc}$ ), causing an array of motor disabilities such as tremor, rigidity and bradykinesia ${ }^{138 .} \mathrm{PD}$ is the second most common neurodegenerative disorder, and, unfortunately, no cure or neuroprotective treatments are yet available, which prompts the need for alternative disease-modifying therapeutic approaches in a near future ${ }^{139 .}$ Thus, electroactive approaches are starting to be explored. A composite scaffold containing 
electrospun PLLA nanofibers, together with glial derived neurotrophic factor (GDNF) embedded on a hydrogel was effective in promoting cell survival and dopaminergic axon growth in vitro as well as in improving the survival of ventral midbrain grafts and reinnervation of the striatum in an in vivo mice model of Parkinson's disease. The observed effects might be attributed to the sustained GDNF release over weeks from the composite scaffold that led to a persistent bound of GDNF allowing a synergistic effect on dopaminergic growth and innervation ${ }^{140}$. Similarly, collagen scaffolds loaded with GDNF also demonstrated positive effects on an ex vivo organotypic brain slice Parkinson's disease model ${ }^{141}$.

Stroke is a global health problem, constituting one of the leading causes of mortality, morbidity and long-term disability worldwide ${ }^{142 .}$ Despite its prevalence and impact for patients, caregivers and society as one, few therapies for stroke recovery are available. In recent years, biomaterial-based therapies have been recognized as attractive approaches to promote tissue repair and functional recovery following stroke ${ }^{143}$. Particularly, considering the electrical properties of the CNS, electroactive polymers have been more and more explored ${ }^{144 .}$ A recent study demonstrated that electrical preconditioning of human neural progenitor cells with a PPy conductive scaffold improved functional outcomes and the post-stroke neurologic environment in vivo. RNASeq results demonstrated that several pathways were involved in hNPCs-increased stroke recovery, particularly regarding angiogenesis, cell proliferation and survival. Furthermore, electrical preconditioning led to the secretion of important regulators of these processes such as vascular endothelial growth factor- A (VEGF-A) and matrix metallopeptidase-9 (MMP-9). The authors proposed that exogenous VEGF-A increases endogenous VEGF-A production and its upstream regulators, being this the primary mechanism that explains the observed in vivo results ${ }^{145}$. Also acting as cell delivery systems, collagen and chitosan, naturally electroactive polymers, 
were combined in a composite with bone marrow MSCs (BMSCs) and its effect evaluated on ischemic stroke. Results have shown a good biocompatibility of cells with scaffold, improved neurological function and reduced pathological changes in the brains of ischemic stroke rats ${ }^{146}$. On a different perspective, the use of carbon nanotubes impregnated with NPCs from the SVZ also provided positive results on cell differentiation and functional recovery ${ }^{147 .}$ Understanding the mechanisms related to in vivo differentiation of stem cells, as well as their behavior in response to lesions in the brain is crucial to consider, define and develop new stem cell-based therapies for repair of the nervous system.

Traumatic brain injury (TBI) is an acute condition that begins with the initial mechanical deformation of the brain parenchyma due to the application of an external physical force ${ }^{148}$. The condition progresses from this primary injury to a myriad of secondary biochemical, cellular and physiological events that ultimately lead to neuroinflammation, axon degeneration and cell death 149. Currently, TBI is a worldwide condition with high morbidity, disability and mortality, for which there are few efficient therapies with the ability to restore lost functions.

The plethora of events following TBI, which include excitotoxicity, inhibition of axonal regeneration, neuroinflammation, oxidative stress and cell death, together with limited availability of neurogenic niches and the intrinsic inhibitory nature of the CNS, constitute a hostile environment for axonal regrowth and successful regeneration in the brain ${ }^{149 .}$ Cell processes such as cell adhesion, orientation, migration and differentiation are processes highly dependent on cell-substrate interactions and external stimuli from the ECM. Biomaterial scaffolds, being able to mimic the natural environment of cells and act as growth-permissive substrates, are a promising strategy to enhance cell survival, neurite extension, and ultimately neuroregeneration of the damaged tissue to restore brain functions ${ }^{150 .}$ Unlike inert biomaterials, 
electroactive materials provide a platform to interact electrically with cells, raising the possibility of enhancing brain repair and regeneration at the injury site.

After severe cases of TBI, a large cranial defect site is formed, which might cause the diffusion of injections or suspension treatments from the site of injury to the surrounding tissue, leading to an ineffective healing process. To address this concern, PCL and PCL-tricalcium phosphate (TCP) scaffolds were designed to act simultaneously as delivery vehicles and structures to support the large cranial defect. Results indicated that PCL-TCP reduced inflammation when compared with PCL scaffolds, conferring a notable advantage for the combined scaffolds. However, none of the scaffolds caused further changes to vascular supply in and around the defect or hindered vascularization ${ }^{151,152 .}$ On a different approach, but also using PCL scaffolds, graphene functionalized PCL microfiber scaffolds were implanted into the striatum or SVZ of adult rats to evaluate the inflammatory responses of microglia and astrocytes. Results demonstrated that PCL graphene-coated scaffolds suppressed microglia and astrocytes activation, while allowing and supporting astrocyte guidance within the scaffold and neuroblast migration from the SVZ ${ }^{153}$. Overall, graphene as a polyelectrolyte multilayer coating on electrospun PCL microfibers appears as a valuable electroactive substrate for brain repair. Different mechanisms have been suggested to explain the bioactive properties of graphene and graphene-based materials, such as electrical coupling between graphene and cells ${ }^{75,154}$ and modulation of bioelectric properties of cellular membranes ${ }^{155}$.

Conductive hydrogels have also appeared as attractive biomaterials to fill the irregular lesion cavity by easy injectable delivery while providing cell migratory cues for regeneration. In fact, fibronectin/PLLA composite fibers dispersed in an agarose/methylcellulose hydrogel implanted within the rat striatum demonstrated ability to integrate infiltrating 
macrophages/microglia and resident astrocytes, providing validation of a tissue engineering scaffold that could be used following brain injury ${ }^{156 .}$ Using an acetylcholine-functionalized graphene oxide hydrogel, Pradhan et al demonstrated its biocompatibility, the ability to promote neurite outgrowth and stabilization of microtubule networks, together with the increase of the expression of some key neural markers, such as growth-associated protein 43 (GAP43), microtubule-associated protein 2 (MAP2) and neuron-specific class III beta-tubulin (Tuj1), in rat cortical primary neurons. Moreover, this hydrogel presented a neuroregenerative potential upon injection on focal brain injury rat models ${ }^{157}$. However, the underlying mechanisms are not described.

Nevertheless, considering the multistep pathophysiology of TBI, therapeutic interventions that target multiple mechanisms simultaneously are expected to present more efficacious results. Tan et al demonstrated that chitosan porous scaffolds combined with BMSCs transplanted into TBI rat models led to improved neurological deficits, together with BMSCs survival, proliferation and differentiation into nerve cells in the lesioned area of the brain ${ }^{158 .}$ Similarly, a combined collagen-chitosan scaffold impregnated with BMSCs also presented positive effects on the recovery of neuropathological injury in TBI rat models ${ }^{159}$. The possible mechanisms behind stem cell-combined biomaterials can range from the differentiation of stem cells into neurons and glial cells, the effect of the secreted molecules by the cells, which will improve the local microenvironment of the lesion, and lastly, the stimulation of the immune system towards an anti-inflammatory state to promote immune regulation and homeostasis.

Overall, the use of electroactive materials offers promising future therapies for SCI and brain injury (Table 2). Nowadays, a great number of investigations are looking into combinatorial approaches, mainly based on the complexity of the pathological process that occur following 
traumatic CNS injuries. In fact, combinations of electroactive materials with stem cells, growth factors or pharmacological compounds have been greatly expanding the therapeutic and regenerative potential of electroactive materials for SCI and brain injury, being one step further as effective strategies to promote successful recovery of neuropathological injury in the CNS.

Table 2 Summary of electroactive materials for neuroregeneration: in vivo proof of concept in the context of spinal cord injury and brain injury

\begin{tabular}{|c|c|c|c|}
\hline & Type of electroactive material & Outcomes & Authors (years) \\
\hline \multirow{6}{*}{ Spinal cord injury } & $\begin{array}{l}\text { Nanofiber hybrid scaffold } \\
\text { PCL/PSA }{ }^{\text {a) }} \text { combined } \\
\text { with } \mathrm{MP}^{\mathrm{b})}\end{array}$ & $\begin{array}{l}\text { Suppression of tissue acute } \\
\text { inflammation and apoptosis; } \\
\text { reduction of glial scar; } \\
\text { improved } \\
\text { regeneration; functional } \\
\text { recovery }\end{array}$ & $\begin{array}{l}\text { Zhang et al } \\
\text { (2018) }\end{array}$ \\
\hline & $\begin{array}{l}\text { PLGA/GO }{ }^{\mathrm{c})} \text { combined with IGF- } \\
1^{\mathrm{d})} \text { and } \mathrm{BDNF}^{\mathrm{e})}\end{array}$ & $\begin{array}{l}\text { Reduced cystic cavity; } \\
\text { increased number of neurons } \\
\text { at the injury site; functional } \\
\text { recovery }\end{array}$ & $\begin{array}{l}\text { Pan et al } \\
\text { (2019) }\end{array}$ \\
\hline & $\begin{array}{l}\text { PLGA/PEG }{ }^{\text {f) }} \text { combined with } \\
\text { iNSCs }^{\mathrm{g})}\end{array}$ & $\begin{array}{l}\text { Long-term survival and } \\
\text { differentiation of iNSCs in } \\
\text { vivo; functional recovery }\end{array}$ & $\begin{array}{l}\text { Liu et al }{ }^{128} \\
(2015)\end{array}$ \\
\hline & $\begin{array}{l}\text { Nanofibrous PCL scaffolds } \\
\text { combinaed with iNSCs and } \mathrm{SC}^{\text {h) }}\end{array}$ & $\begin{array}{l}\text { Tissue remodeling; } \\
\text { functional recovery }\end{array}$ & $\begin{array}{l}\text { Zhou et al }{ }^{129} \\
\text { (2018) }\end{array}$ \\
\hline & PVDF-TrFE ${ }^{\mathrm{i})}$ conduits with SC & $\begin{array}{l}\text { Regeneration of sensory and } \\
\text { brainstem axons across the } \\
\text { aligned fibers of the conduit; } \\
\text { blood vessel formation; no } \\
\text { behavioral assessment }\end{array}$ & $\begin{array}{l}\text { Wu et al }{ }^{130} \\
(2018)\end{array}$ \\
\hline & $\begin{array}{l}\text { PLLA }^{\mathrm{j})} \text { multi-channel conduits } \\
\text { with } \mathrm{NNCs}^{\mathrm{k})}\end{array}$ & $\begin{array}{l}\text { Reduction of inflammation } \\
\text { and accumulation of } \\
\text { astrocyte/collagen scar, } \\
\text { orientation control of axonal } \\
\text { growth on the scaffolds }\end{array}$ & $\begin{array}{l}\text { Sun } \text { et al }{ }^{131} \\
\text { (2019) }\end{array}$ \\
\hline
\end{tabular}


TA/PPy ${ }^{1)}$ hydrogel

Activation of endogenous $\mathrm{NSCs}^{\mathrm{m})}$ neurogenesis in the lesion area, resulting in significant motor recovery

Zhou et al ${ }^{132}$

$\mathrm{CNTs}^{\mathrm{n})}$ engrafted with OB$\mathrm{NSCs}^{\mathrm{o})}$

PLLA/GDNF ${ }^{q)}$ hydrogel

Preconditioning of $\mathrm{NPCs}^{\mathrm{t}}$ ) with PPy

Collagen/chitosan composite combined with BMSCs ${ }^{\text {u) }}$

CNTs impregnated with NPCs

PCL and PCL-TCPv) scaffolds
Restoration of cognitive deficits and neurodegenerative alterations of TMT $^{\mathrm{p}}$-induced rat neurodegeneration model

Marei et al ${ }^{137}$

Promotion of cell survival and dopaminergic axon growth in vitro; improvement of survival of ventral midbrain grafts and reinnervation of the striatum in an in vivo mice model of $\mathrm{PD}^{\mathrm{r})}$

Wang et al ${ }^{140}$

(2016)

\begin{tabular}{|c|c|}
\hline 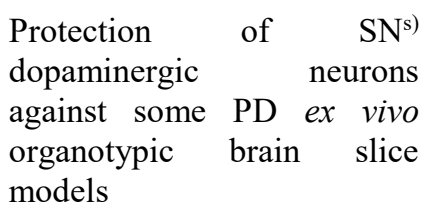 & Ucar et al ${ }^{141}$ \\
\hline $\begin{array}{l}\text { Improvement of functional } \\
\text { outcomes and post-stroke } \\
\text { neurologic environment in } \\
\text { vivo }\end{array}$ & $\begin{array}{l}\text { George et al }{ }^{145} \\
(2017)\end{array}$ \\
\hline $\begin{array}{l}\text { Improvement of neurological } \\
\text { function and reduced } \\
\text { pathological changes in the } \\
\text { brains of ischemic stroke rat } \\
\text { models }\end{array}$ & $\begin{array}{l}\text { Yan et al }{ }^{146} \\
(2015)\end{array}$ \\
\hline $\begin{array}{l}\text { Improvement of cell } \\
\text { differentiation to heal stroke } \\
\text { damage }\end{array}$ & $\begin{array}{l}\text { Moon et al }{ }^{147} \\
\text { (2012) }\end{array}$ \\
\hline $\begin{array}{l}\text { Support large cranial defect } \\
\text { of } \mathrm{TBI}^{\mathrm{w})} \text {; reduction of } \\
\text { inflammation in TBI models } \\
\text { with PCL-TCP scaffolds }\end{array}$ & $\begin{array}{l}\text { Nga et al }{ }^{151} \text { (2015) } \\
\text { Choy et al } \\
(2013) 135\end{array}$ \\
\hline
\end{tabular}




\begin{tabular}{|c|c|c|c|c|}
\hline $\begin{array}{l}\text { Graphene } \\
\text { scaffolds }\end{array}$ & functionalized & PCL & $\begin{array}{l}\text { Suppression of microglia and } \\
\text { astrocytes activation into the } \\
\text { striatum and SVZ } \\
\text { rats and neuroblast migration }\end{array}$ & $\begin{array}{l}\text { Zhou et al }{ }^{153} \\
\text { (2016) }\end{array}$ \\
\hline
\end{tabular}

$\mathrm{FN}^{\mathrm{y}} /$ PLLA composite fibers in agarose/methylcellulose hydrogel

$\mathrm{Ach}^{2} / \mathrm{GO}$ hydrogel

$\mathrm{Cs}^{\text {aa) }}$ porous scaffolds with BMSCs

Collagen/Cs scaffold with BMSCs
Integration of infiltrating macrophages/microglia and resident astrocytes in the striatum

Neurite outgrowth of rat cortical primary neurons; neuroregenerative potential upon injection on focal brain injury rat models

Rivet et al ${ }^{156}$

Pradhan et al ${ }^{157}$

Improved neurological deficits of TBI rat models

Improved recovery of
neuropathological injury in TBI rat models
Tan et al

Yan et al ${ }^{159}$

(2019)

Poly(caprolactone) (PCL); polysialic acid (PSA); b) methylprednisolone (MP); ${ }^{\mathrm{c})}$ poly(lactic-coglycolic acid) (PLGA); graphene oxide (GO); d) insulin-like growth factor 1 (IGF-1); e) brainderived neurotrophic factor (BDNF); ${ }^{\text {f) }}$ poly(lactic-co-glycolic acid) (PLGA); polyethylene glycol (PEG); ${ }^{\mathrm{g})}$ human induced pluripotent stem cell-derived neural stem cells (iNSCs); ${ }^{\mathrm{h}}$ ) Schwann cells (SC); i) polyvinylidene fluoride trifluoroethylene (PVDF-TrFE); j) poly-L-lactic acid (PLLA); ${ }^{k}$ nano-fibrous channel wall (NNCs); ${ }^{1)}$ tannic acid (TA); Polypyrrole (PPy); ${ }^{\mathrm{m})}$ neural stem cells (NSCs); ${ }^{\text {n) }}$ carbon nanotube (CNT); ${ }^{o)}$ olfactory bulb (OB); p) trimethyltin chloride (TMT); ${ }^{\text {q) }}$ glial derived neurotrophic factor (GDNF); ${ }^{\text {r) }}$ Parkinson's disease (PD); ${ }^{\text {s) }}$ substantia nigra (SN); ${ }^{\text {t) }}$ human neural progenitor cells (NPCs); ${ }^{u}$ bone marrow mesenchymal stem cells (BMSCs); ${ }^{v)}$ tricalcium phosphate (TCP); ${ }^{\text {w) }}$ traumatic brain injury (TBI); ${ }^{\mathrm{x})}$ subventricular zone (SVZ); ${ }^{\mathrm{y})}$ fibronectin (FN); ${ }^{\mathrm{z})}$ acetylcholine (ACh); ${ }^{\text {aa) }}$ chitosan (Cs).

4. Major challenges and future directions

The concept of one-size fits all no longer applies to the rapidly evolving biomedical field, urging the need for precise therapeutic approaches. A relevant advantage of electroactive 
materials resides in the fact that these materials retain some of the processable and favorable characteristics of polymers, allowing optimization and further functionalization to control physical, chemical and biological properties for tailored and versatile applications ${ }^{13}$. In fact, the paradigm of scaffolds design and applicability for tissue regeneration shifted from the use of materials in a passive way, just as supporting structures for cells and tissues or vehicles for drug delivery, to active materials that provide a (often time dependent) behavior which is useful and necessary for effective tissue regeneration ${ }^{160 .}$

As described here, promising results have been achieved for tissue regeneration approaches using electroactive smart materials, both in vitro and in vivo (Figure 2), however, so far, few materials have successfully met the demand of clinical need. Failure of these strategies can be mainly attributed to the immense complexity of the nervous system: on one end, and although electroactive materials have demonstrated the ability to promote growth and differentiation of neurons, the restoration of neural circuits and functional connectivity is still a long way ahead; on the other end, the inhibitory nature of the injured CNS constitutes another major barrier for neural regeneration. Besides, after implantation at the injury site, biomaterials encounter a physiologically complex and dynamic environment, that might impact the structural integrity of the material, and its functionality in the tissue. Progress in understanding all the functional requirements of neural regeneration would significantly increase the probability of success of tissue engineered-smart material scaffolds. Depending on the intended use, electroactive polymers can be synthetic or biologic, degradable or non-degradable. Natural polymers, such as collagen and cellulose, are biologically active scaffolds with the advantage to be biodegradable. However, the risk of some degree of inflammation can't be discarded. On the other hand, synthetic polymers, which the vast majority are also biodegradable, can be tailored to specific 
needs and applications, have defined and reproducible properties such as physical and mechanical features, porosity and specific degradation rates. From a translational point of view, methodologies and techniques able to monitor biomaterials at the lesion site, either from a molecular or structural perspective, should also be designed. Parameters such as response to physical/chemical stimuli and controlled biodegradability should be carefully monitored to facilitate future research processes 161 .

Going forward, and looking at the complexities of the CNS, it is very unlikely that a biomaterial aimed at only one specific target will lead to a successful axonal regeneration and functional recovery after injury. Moreover, smart approaches should consider different tissue engineering components, such as stiffness, electro-conductive properties and spatial structure to have the best opportunity for achieving efficacious repair.

Overall, given the electrical, mechanical and chemical interactions of the CNS, and although research in the field is still facing challenging issues, the promising results obtained with electroactive materials suggest this class of biomaterials as platforms for recovery of the neural tissue. In the near future, relevant advances are expected in this field, shortening the way towards clinical applications.

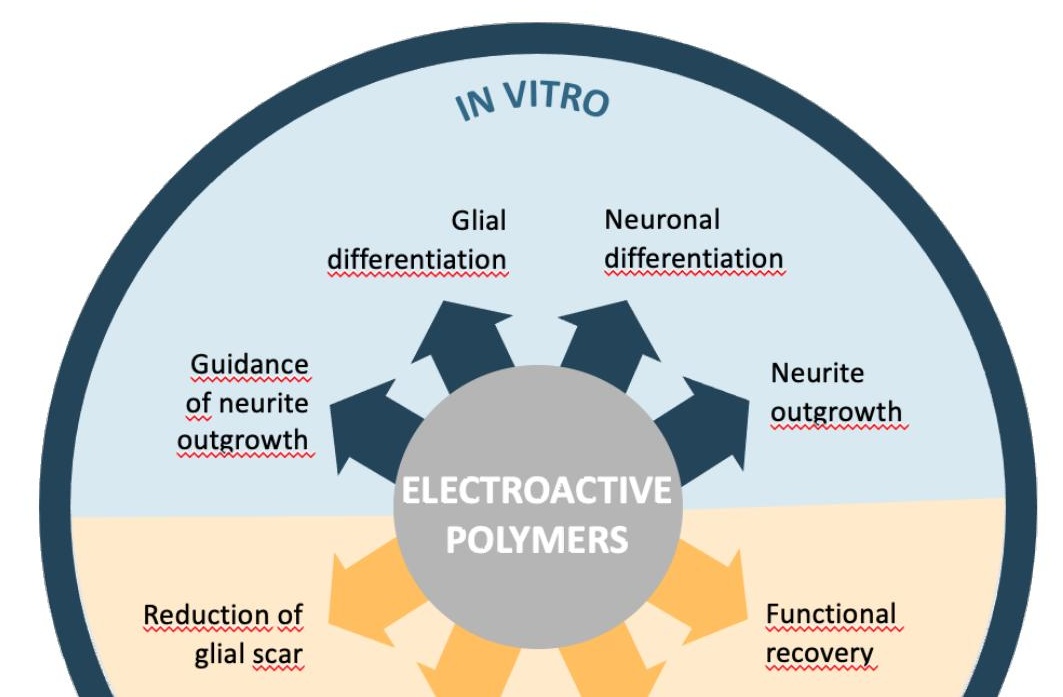


Figure 2. Schematic overview. Electroactive polymers offer a fulfilling role for neuroregenerative approaches, both in vitro and in vivo ${ }^{13,34,39,47,48,55,68,136,160}$.

\section{Final remarks}

Neural disorders still remain a clinical challenge nowadays. Traditional therapeutic strategies have been focused on alleviation of the symptoms and improving patient's quality of life. Although some progresses have been achieved, no routes that reverse neurological damage have yet arise. Therefore, there is an urgent need to develop novel therapeutic strategies to tackle the pathophysiological neurodegeneration observed. Biomaterial-based therapies have been pinpointed to lead to efficient neural regeneration and functional outcomes after injury. Narrowing it down to electroactive materials, the studies described above have shown their biocompatibility, regenerative abilities in vitro, some molecular pathways underlying these effects, and functional and neurological recovery capabilities in different neural-related disease contexts. Moreover, smart materials also resulted in being optimal substrates for the delivery of cells, growth factors or pharmacological approaches to the site of the injury, further potentiating 
cell growth, differentiation and regeneration. In fact, to achieve successful tissue repair and regeneration, combination of biochemical, electrical, mechanical and physiological cues has been shown to improve functional recovery after injury. Nonetheless, several aspects still need to be considered and addressed in this field for future clinical applications.

Overall, electroactive materials are raising as new disease-modifying therapies that offer the possibility of improving neural repair and regeneration, re-establishing functionality at both the cellular and organ levels. Although these strategies present a great potential to provide therapeutic benefit in the future, a long way still waits ahead until the clinic translation. However, as the field progresses, and investigation expands our understanding of the nervous system, relevant advances are expected from these biomaterials, shortening the way to efficient approaches for neuroregeneration.

Author information

* Corresponding author: Senentxu Lanceros-Méndez

Email: senenxtu.lanceros@bcmaterials.net

Notes

The authors declare no competing financial interest.

Author contributions

The manuscript was written through contributions of all authors. All authors have given approval to the final version of the manuscript. 
Acknowledgments

This work was supported by Prémios Santa Casa Neurociências-Prize Melo e Castro for Spinal Cord Injury Research (MC-04/17) and Portuguese Foundation for Science and Technology (Ph.D. fellowship to T. S. Pinho [PD/BDE/143150/2019]. This work was funded by national funds and FEDER, through the Foundation for Science and Technology (FCT), under the scope of the projects UIDB/50026/2020; UIDP/50026/2020; POCI-01-0145-FEDER-029206; POCI-01-0145-FEDER-031392; PTDC/ MED-NEU/31417/2017; NORTE-01-0145-FEDER029968; POCI-01-0145-FEDER-029751 POCI-01-0145-FEDER-032619. This work has also been developed under the scope of the project NORTE-01-0145- FEDER-000013 and NORTE01-0145-FEDER-000023, supported by the Northern Portugal Regional Operational Programme (NORTE 2020), under the Portugal 2020 Partnership Agreement, through the European Regional Development Fund (FEDER). Work supported by the Portuguese Foundation for Science and Technology (FCT): projects UID/FIS/04650/2020, PTDC/EMD-EMD/28159/2017 and PTDC/BTM-MAT/28237/2017. Financial support from the Spanish State Research Agency (AEI) and the European Regional Development Fund (ERFD) through the project PID2019106099RB-C43/AEI/10.13039/501100011033 and from the Basque Government Industry and Education Departments under the ELKARTEK and PIBA (PIBA-2018-06) programs, respectively, area also acknowledged.

References

(1) Tuladhar, A.; Mitrousis, N.; Führmann, T.; Shoichet, M. S. Central Nervous System. In Translational Regenerative Medicine; Atala, A., Allickson, J., Eds.; Elsevier Inc., 2015; 
pp 415-435. https://doi.org/10.1016/B978-0-12-410396-2.00030-X.

(2) Curcio, M.; Bradke, F. Axon Regeneration in the Central Nervous System: Facing the Challenges from the Inside. Annu. Rev. Cell Dev. Biol. 2018, 34 (1), 495-521. https://doi.org/10.1146/annurev-cellbio-100617-062508.

(3) Tam, R. Y.; Fuehrmann, T.; Mitrousis, N.; Shoichet, M. S. Regenerative Therapies for Central Nervous System Diseases: A Biomaterials Approach. Neuropsychopharmacology. Nature Publishing Group January 4, 2014, pp 169-188. https://doi.org/10.1038/npp.2013.237.

(4) Dolcimascolo, A.; Calabrese, G.; Conoci, S.; Parenti, R. Innovative Biomaterials for Tissue Engineering. Biomater. Tissue Reconstr. or Regen. 2019. https://doi.org/10.5772/INTECHOPEN.83839.

(5) Kaliva, M.; Chatzinikolaidou, M.; Vamvakaki, M. Applications of Smart Multifunctional Tissue Engineering Scaffolds. In RSC Smart Materials; Royal Society of Chemistry, 2017; Vol. 2017-Janua, pp 1-38. https://doi.org/10.1039/9781788010542-00001.

(6) Wang, Y.; Tan, H.; Hui, X. Biomaterial Scaffolds in Regenerative Therapy of the Central Nervous System. Biomed Res. Int. 2018, 2018 (7848901), 1-19. https://doi.org/10.1155/2018/7848901.

(7) Dhandayuthapani, B.; Yoshida, Y.; Maekawa, T.; Kumar, D. S. Polymeric Scaffolds in Tissue Engineering Application: A Review. Int. J. Polym. Sci. 2011, 2011 (290602), 1-19. https://doi.org/10.1155/2011/290602.

(8) Rahmati, M.; Pennisi, C. P.; Budd, E.; Mobasheri, A.; Mozafari, M. Biomaterials for 
Regenerative Medicine: Historical Perspectives and Current Trends. Adv. Exp. Med. Biol. 2018, 1119,1-19. https://doi.org/10.1007/5584_2018_278.

(9) Zhu, Y.; Wagner, W. R. Design Principles in Biomaterials and Scaffolds. In Principles of Regenerative Medicine; Elsevier Inc., 2019; pp 505-522. https://doi.org/10.1016/b978-012-809880-6.00030-8.

(10) Frantz, C.; Stewart, K. M.; Weaver, V. M. The Extracellular Matrix at a Glance. Journal of Cell Science. Company of Biologists December 15, 2010, pp 4195-4200. https://doi.org/10.1242/jcs.023820.

(11) Ozdil, D.; Aydin, H. M. Polymers for Medical and Tissue Engineering Applications. $J$. Chem. Technol. Biotechnol. 2014, 89 (12), 1793-1810. https://doi.org/10.1002/jctb.4505.

(12) Brown, B. N.; Badylak, S. F. Extracellular Matrix as an Inductive Scaffold for Functional Tissue Reconstruction. Translational Research. Mosby Inc. 2014, pp 268-285. https://doi.org/10.1016/j.trsl.2013.11.003.

(13) Palza, H.; Zapata, P. A.; Angulo-Pineda, C. Electroactive Smart Polymers for Biomedical Applications. Materials (Basel). 2019, 12 (2), 277. https://doi.org/10.3390/ma12020277.

(14) Zhao, J.; Lee, V. E.; Liu, R.; Priestley, R. D. Responsive Polymers as Smart Nanomaterials Enable Diverse Applications. Annu. Rev. Chem. Biomol. Eng. 2019, 10 (1), 361-382. https://doi.org/10.1146/annurev-chembioeng-060718-030155.

(15) Roentgen, W. About the Changes in Shape and Volume of Dielectrics Caused by Electricity. Annu. Rev. Phys. Chem. 1880, 11, 771-786.

(16) Bar-Cohen, Y.; Cardoso, V. F.; Ribeiro, C.; Lanceros-Méndez, S. Electroactive Polymers 
as Actuators. In Advanced Piezoelectric Materials; 2017; pp 319-352. https://doi.org/10.1016/b978-0-08-102135-4.00008-4.

(17) Sacerdote, M. On the Electrical Deformation of Isotropic Dielectric Solids. J. Phys. 1899, 31 (3 Series, t, VIII), 282-285.

(18) Eguchi, M. On the Permanent Electret. Philos. Mag. 1925, 49, 178.

(19) Kao, K. C. Electrets. In Dielectric Phenomena in Solids; Academic Press, 2004; pp 283326.

(20) Kawai, H. The Piezoelectricity of Poly (Vinylidene Fluoride). Jpn. J. Appl. Phys. 1969, 8 (7), 975-976. https://doi.org/10.1143/jjap.8.975.

(21) Bar-Cohen, Y.; Anderson, I. A. Electroactive Polymer (EAP) Actuators-Background Review. Mech. Soft Mater. 2019, 1 (1), 5. https://doi.org/10.1007/s42558-019-0005-1.

(22) Bar-Cohen, Y. Current and Future Developments in Artificial Muscles Using Electroactive Polymers. Expert Rev. Med. Devices 2005, 2 (6), 731-740. https://doi.org/10.1586/17434440.2.6.731.

(23) Ribeiro, C.; Costa, C. M.; Correia, D. M.; Nunes-pereira, J.; Oliveira, J.; Martins, P.; Gonçalves, R.; Cardoso, V. F.; Lanceros-méndez, S. Electroactive Poly (Vinylidene Fluoride) -Based Structures for Advanced Applications. Nat. Publ. Gr. 2018, 13 (4), 681704. https://doi.org/10.1038/nprot.2017.157.

(24) Ribeiro, C.; Correia, D. M.; Ribeiro, S.; Fernandes, M. M.; Lanceros-Mendez, S. Piezoand Magnetoelectric Polymers as Biomaterials for Novel Tissue Engineering Strategies. MRS Adv. 2018, 3 (30), 1671-1676. https://doi.org/10.1557/adv.2018.223. 
(25) Tandon, B.; Magaz, A.; Balint, R.; Blaker, J. J.; Cartmell, S. H. Electroactive Biomaterials: Vehicles for Controlled Delivery of Therapeutic Agents for Drug Delivery and Tissue Regeneration. Adv. Drug Deliv. Rev. 2018, 129, 148-168. https://doi.org/10.1016/j.addr.2017.12.012.

(26) Fernandes, M. M.; Carvalho, E. O.; Lanceros-Mendez, S. Electroactive Smart Materials: Novel Tools for Tailoring Bacteria Behavior and Fight Antimicrobial Resistance. Frontiers in Bioengineering and Biotechnology. Frontiers Media S.A. October 18, 2019. https://doi.org/10.3389/fbioe.2019.00277.

(27) Allen, S. A. B. Dielectric Techniques. In Handbook of Thermal Analysis and Calorimetry; Elsevier Science B.V., 1998; Vol. 1, pp 401-422. https://doi.org/10.1016/S15734374(98)80010-1.

(28) Page, H. Piezoelectric Materials, A Review of Progress. Proc. IEE Part B Electron. Commun. Eng. 1961, 108 (41), 473. https://doi.org/10.1049/pi-b-2.1961.0079.

(29) Chorsi, M. T.; Curry, E. J.; Chorsi, H. T.; Das, R.; Baroody, J.; Purohit, P. K.; Ilies, H.; Nguyen, T. D. Piezoelectric Biomaterials for Sensors and Actuators. Adv. Mater. 2019, 31 (1), 1-15. https://doi.org/10.1002/adma.201802084.

(30) Curie, J.; Curie, P. Développement Par Compression de l'électricité Polaire Dans Les Cristaux Hémièdres à Faces Inclinées. Bull. la Société minéralogique Fr. 1880, 3 (4), 9093. https://doi.org/10.3406/bulmi.1880.1564.

(31) Zaszczynska, A.; Sajkiewicz, P.; Gradys, A. Piezoelectric Scaffolds as Smart Materials for Neural Tissue Engineering. Polymers (Basel). 2020, 12 (1), 161. 
https://doi.org/10.3390/polym12010161.

(32) Rajabi, A. H.; Jaffe, M.; Arinzeh, T. L. Piezoelectric Materials for Tissue Regeneration: A $\begin{array}{llllll}\text { Review. } & \text { Acta } & \text { Biomater. } & \text { 2015, } & 24 & \text { (July), }\end{array}$ https://doi.org/10.1016/j.actbio.2015.07.010.

(33) Chen-Glasser, M.; Li, P.; Ryu, J.; Hong, S. Piezoelectric Materials for Medical Applications. In Piezoelectricity - Organic and Inorganic Materials and Applications; InTech, 2018. https://doi.org/10.5772/intechopen.76963.

(34) Shin, D. M.; Hong, S. W.; Hwang, Y. H. Recent Advances in Organic Piezoelectric Biomaterials for Energy and Biomedical Applications. Nanomaterials 2020, 10 (1), 123. https://doi.org/10.3390/nano10010123.

(35) Khan, F.; Tanaka, M. Designing Smart Biomaterials for Tissue Engineering. Int. J. Mol. Sci. 2018, 19 (1), 17. https://doi.org/10.3390/ijms19010017.

(36) Guiseppi-Elie, A. Electroconductive Hydrogels: Synthesis, Characterization and Biomedical Applications. Biomaterials. April 2010, pp 2701-2716. https://doi.org/10.1016/j.biomaterials.2009.12.052.

(37) Lee, J.-H.; Kim, H.-W. Emerging Properties of Hydrogels in Tissue Engineering. J. Tissue Eng. 2018, 9, 2041731418768285. https://doi.org/10.1177/2041731418768285.

(38) Ravichandran, R.; Sundarrajan, S.; Venugopal, J. R.; Mukherjee, S.; Ramakrishna, S. Applications of Conducting Polymers and Their Issues in Biomedical Engineering. Journal of the Royal Society Interface. Royal Society October 6, 2010, p S559. https://doi.org/10.1098/rsif.2010.0120.focus. 
(39) Tomczykowa, M.; Plonska-Brzezinska, M. E. Conducting Polymers, Hydrogels and Their Composites: Preparation, Properties and Bioapplications. Polymers. MDPI AG February 17, 2019, p 350. https://doi.org/10.3390/polym11020350.

(40) Wang, T.; Farajollahi, M.; Choi, Y. S.; Lin, I. T.; Marshall, J. E.; Thompson, N. M.; KarNarayan, S.; Madden, J. D. W.; Smoukov, S. K. Electroactive Polymers for Sensing. Interface Focus. Royal Society of London August 6, 2016. https://doi.org/10.1098/rsfs.2016.0026.

(41) Balint, R.; Cassidy, N. J.; Cartmell, S. H. Conductive Polymers: Towards a Smart Biomaterial for Tissue Engineering. Acta Biomaterialia. Elsevier Ltd June 1, 2014, pp 2341-2353. https://doi.org/10.1016/j.actbio.2014.02.015.

(42) Letheby, H. On the Production of a Blue Substance by the Electrolysis of Sulphate of Aniline. J. Chem. Soc. 1862, 15 (0), 161-163. https://doi.org/10.1039/JS8621500161.

(43) Chiang, C. K.; Fincher, C. R.; Park, Y. W.; Heeger, A. J.; Shirakawa, H.; Louis, E. J.; Gau, S. C.; MacDiarmid, A. G. Electrical Conductivity in Doped Polyacetylene. Phys. Rev. Lett. 1977, 39 (17), 1098-1101. https://doi.org/10.1103/PhysRevLett.39.1098.

(44) Shirakawa, H.; Louis, E. J.; MacDiarmid, A. G.; Chiang, C. K.; Heeger, A. J. Synthesis of Electrically Conducting Organic Polymers: Halogen Derivatives of Polyacetylene, $(\mathrm{CH}) \mathrm{X}$. J. Chem. Soc. Chem. Commun. 1977, No. 16, 578-580. https://doi.org/10.1039/C39770000578.

(45) The Nobel Prize in Chemistry 2000 https://www.nobelprize.org/prizes/chemistry/2000/summary/ (accessed Jun 10, 2020). 
(46) Ateh, D. .; Navsaria, H. .; Vadgama, P. Polypyrrole-Based Conducting Polymers and Interactions with Biological Tissues. J. R. Soc. Interface 2006, 3 (11), 741-752. https://doi.org/10.1098/rsif.2006.0141.

(47) Ning, C.; Zhou, Z.; Tan, G.; Zhu, Y.; Mao, C. Electroactive Polymers for Tissue Regeneration: Developments and Perspectives. Progress in Polymer Science. Elsevier Ltd June 1, 2018, pp 144-162. https://doi.org/10.1016/j.progpolymsci.2018.01.001.

(48) Kaur, G.; Adhikari, R.; Cass, P.; Bown, M.; Gunatillake, P. Electrically Conductive Polymers and Composites for Biomedical Applications. RSC Adv. 2015, 5 (47), 3755337567. https://doi.org/10.1039/C5RA01851J.

(49) Allen, M. J.; Tung, V. C.; Kaner, R. B. Honeycomb Carbon: A Review of Graphene. Chem. Rev. 2010, 110 (1), 132-145. https://doi.org/10.1021/cr900070d.

(50) Goenka, S.; Sant, V.; Sant, S. Graphene-Based Nanomaterials for Drug Delivery and Tissue Engineering. Journal of Controlled Release. J Control Release 2014, pp 75-88. https://doi.org/10.1016/j.jconrel.2013.10.017.

(51) Aydin, T.; Gurcan, C.; Taheri, H.; Yilmazer, A. Graphene Based Materials in Neural Tissue Regeneration. In Advances in Experimental Medicine and Biology; Springer New York LLC, 2018; Vol. 1107, pp 129-142. https://doi.org/10.1007/5584_2018_221.

(52) Bei, H. P.; Yang, Y.; Zhang, Q.; Tian, Y.; Luo, X.; Yang, M.; Zhao, X. Graphene-Based Nanocomposites for Neural Tissue Engineering. Molecules 2019, 24 (4), 658. https://doi.org/10.3390/molecules24040658.

(53) Yu, X.; Cheng, H.; Zhang, M.; Zhao, Y.; Qu, L.; Shi, G. Graphene-Based Smart 
Materials. Nat. Rev. Mater. 2017, 2, 1-14. https://doi.org/10.1038/natrevmats.2017.46.

(54) Fabbro, A.; Prato, M.; Ballerini, L. Carbon Nanotubes in Neuroregeneration and Repair. Advanced Drug Delivery Reviews. Adv Drug Deliv Rev December 2013, pp 2034-2044. https://doi.org/10.1016/j.addr.2013.07.002.

(55) John, A. A.; Subramanian, A. P.; Vellayappan, M. V.; Balaji, A.; Mohandas, H.; Jaganathan, S. K. Carbon Nanotubes and Graphene as Emerging Candidates in Neuroregeneration and Neurodrug Delivery. International Journal of Nanomedicine. Dove Medical Press Ltd. 2015, pp 4267-4277. https://doi.org/10.2147/IJN.S83777.

(56) Dugger, B. N.; Dickson, D. W. Pathology of Neurodegenerative Diseases. Cold Spring Harb. Perspect. Biol. 2017, 9 (7), a028035. https://doi.org/10.1101/cshperspect.a028035.

(57) Shoichet, M. S.; Tate, C. C.; Douglas Baumann, M.; LaPlaca, M. C. Strategies for Regeneration and Repair in the Injured Central Nervous System. In Indwelling Neural Implants: Strategies for Contending with the in Vivo Environment; CRC Press, 2007; pp 221-244. https://doi.org/10.1201/9781420009309.ch8.

(58) Ji, F. and S. R. Electroactive Polymers for Tissue Regeneration: Developments and $\begin{array}{lllllll}\text { Perspectives. Prog Polym } & \text { Sci 2019, } 176 & \text { (3), 139-148. }\end{array}$ https://doi.org/10.1016/j.physbeh.2017.03.040.

(59) Altman, J.; Das, G. D. Autoradiographic and Histological Evidence of Postnatal Hippocampal Neurogenesis in Rats. J. Comp. Neurol. 1965, 124 (3), 319-335. https://doi.org/10.1002/cne.901240303.

(60) Eriksson, P. S.; Perfilieva, E.; Björk-Eriksson, T.; Alborn, A. M.; Nordborg, C.; Peterson, 
D. A.; Gage, F. H. Neurogenesis in the Adult Human Hippocampus. Nat. Med. 1998, 4 (11), 1313-1317. https://doi.org/10.1038/3305.

(61) Lois, C.; Alvarez-Buylla, A. Proliferating Subventricular Zone Cells in the Adult Mammalian Forebrain Can Differentiate into Neurons and Glia. Proc. Natl. Acad. Sci. U. S. A. 1993, 90 (5), 2074-2077. https://doi.org/10.1073/pnas.90.5.2074.

(62) Zhao, Y.; Xiao, Z.; Chen, B.; Dai, J. The Neuronal Differentiation Microenvironment Is Essential for Spinal Cord Injury Repair. Organogenesis 2017, 13 (3), 63-70. https://doi.org/10.1080/15476278.2017.1329789.

(63) Sun, D. The Potential of Endogenous Neurogenesis for Brain Repair and Regeneration Following Traumatic Brain Injury. Neural Regen. Res. 2014, 9 (7), 688-692. https://doi.org/10.4103/1673-5374.131567.

(64) Stewart, E.; Kobayashi, N. R.; Higgins, M. J.; Quigley, A. F.; Jamali, S.; Moulton, S. E.; Kapsa, R. M. I.; Wallace, G. G.; Crook, J. M. Electrical Stimulation Using Conductive Polymer Polypyrrole Promotes Differentiation of Human Neural Stem Cells: A Biocompatible Platform for Translational Neural Tissue Engineering. Tissue Eng. - Part C Methods 2015, 21 (4), 385-393. https://doi.org/10.1089/ten.tec.2014.0338.

(65) Zou, Y.; Qin, J.; Huang, Z.; Yin, G.; Pu, X.; He, D. Fabrication of Aligned Conducting PPy-PLLA Fiber Films and Their Electrically Controlled Guidance and Orientation for Neurites. ACS Appl. Mater. Interfaces 2016, 8 (20), 12576-12582. https://doi.org/10.1021/acsami.6b00957.

(66) Xu, Y.; Huang, Z.; Pu, X.; Yin, G.; Zhang, J. Fabrication of Chitosan/Polypyrrole-Coated 
Poly(L-Lactic Acid)/Polycaprolactone Aligned Fibre Films for Enhancement of Neural Cell Compatibility and Neurite Growth. Cell Prolif. 2019, 52 (3), e12588-e12588. https://doi.org/10.1111/cpr.12588.

(67) Zhou, X.; Yang, A.; Huang, Z.; Yin, G.; Pu, X.; Jin, J. Enhancement of Neurite Adhesion, Alignment and Elongation on Conductive Polypyrrole-Poly(Lactide Acid) Fibers with Cell-Derived Extracellular Matrix. Colloids Surfaces B Biointerfaces 2017, 149, 217-225. https://doi.org/10.1016/j.colsurfb.2016.10.014.

(68) Balint, R.; Cassidy, N. J.; Cartmell, S. H. Conductive Polymers: Towards a Smart Biomaterial for Tissue Engineering. Acta Biomaterialia. Elsevier Ltd June 2014, pp 23412353. https://doi.org/10.1016/j.actbio.2014.02.015.

(69) Magaz, A.; Spencer, B. F.; Hardy, J. G.; Li, X.; Gough, J. E.; Blaker, J. J. Modulation of Neuronal Cell Affinity on PEDOT-PSS Nonwoven Silk Scaffolds for Neural Tissue Engineering. ACS Biomater. Sci. Eng. 2020, $6 \quad$ (12), 6906-6916. https://doi.org/10.1021/acsbiomaterials.0c01239.

(70) Ritzau-Reid, K. I.; Spicer, C. D.; Gelmi, A.; Grigsby, C. L.; Ponder, J. F.; Bemmer, V.; Creamer, A.; Vilar, R.; Serio, A.; Stevens, M. M. An Electroactive Oligo-EDOT Platform for Neural Tissue Engineering. Adv. Funct. Mater. 2020, 2003710. https://doi.org/10.1002/adfm.202003710.

(71) Li, N.; Zhang, X.; Song, Q.; Su, R.; Zhang, Q.; Kong, T.; Liu, L.; Jin, G.; Tang, M.; Cheng, G. The Promotion of Neurite Sprouting and Outgrowth of Mouse Hippocampal Cells in Culture by Graphene Substrates. Biomaterials 2011, 32 (35), 9374-9382. https://doi.org/10.1016/j.biomaterials.2011.08.065. 
(72) Chiacchiaretta, M.; Bramini, M.; Rocchi, A.; Armirotti, A.; Giordano, E.; Vázquez, E.; Bandiera, T.; Ferroni, S.; Cesca, F.; Benfenati, F. Graphene Oxide Upregulates the Homeostatic Functions of Primary Astrocytes and Modulates Astrocyte-to-Neuron Communication. Nano Lett. $2018, \quad 18 \quad$ (9), 5827-5838. https://doi.org/10.1021/acs.nanolett.8b02487.

(73) Park, S. Y.; Park, J.; Sim, S. H.; Sung, M. G.; Kim, K. S.; Hong, B. H.; Hong, S. Enhanced Differentiation of Human Neural Stem Cells into Neurons on Graphene. $A d v$. Mater. 2011, 23 (36), H263-H267. https://doi.org/10.1002/adma.201101503.

(74) Guo, W.; Qiu, J.; Liu, J.; Liu, H. Graphene Microfiber as a Scaffold for Regulation of Neural Stem Cells Differentiation. Sci. Rep. 2017, $7 \quad$ (1), 1-8. https://doi.org/10.1038/s41598-017-06051-z.

(75) Tang, M.; Song, Q.; Li, N.; Jiang, Z.; Huang, R.; Cheng, G. Enhancement of Electrical Signaling in Neural Networks on Graphene Films. Biomaterials 2013, 34 (27), 64026411. https://doi.org/10.1016/j.biomaterials.2013.05.024.

(76) Li, N.; Zhang, Q.; Gao, S.; Song, Q.; Huang, R.; Wang, L.; Liu, L.; Dai, J.; Tang, M.; Cheng, G. Three-Dimensional Graphene Foam as a Biocompatible and Conductive Scaffold for Neural Stem Cells. Sci. Rep. 2013, 3, 1604. https://doi.org/10.1038/srep01604.

(77) Ma, Q.; Yang, L.; Jiang, Z.; Song, Q.; Xiao, M.; Zhang, D.; Ma, X.; Wen, T.; Cheng, G. Three-Dimensional Stiff Graphene Scaffold on Neural Stem Cells Behavior. ACS Appl. Mater. Interfaces 2016, 8 (50), 34227-34233. https://doi.org/10.1021/acsami.6b12305. 
(78) Hwang, J. Y.; Shin, U. S.; Jang, W. C.; Hyun, J. K.; Wall, I. B.; Kim, H. W. Biofunctionalized Carbon Nanotubes in Neural Regeneration: A Mini-Review. Nanoscale. Royal Society of Chemistry January 21, 2013, pp 487-497. https://doi.org/10.1039/c2nr31581e.

(79) Matsumoto, K.; Sato, C.; Naka, Y.; Whitby, R.; Shimizu, N. Stimulation of Neuronal Neurite Outgrowth Using Functionalized Carbon Nanotubes. Nanotechnology 2010, 21 (11), 115101. https://doi.org/10.1088/0957-4484/21/11/115101.

(80) Lee, S. J.; Zhu, W.; Nowicki, M.; Lee, G.; Heo, D. N.; Kim, J.; Zuo, Y. Y.; Zhang, L. G. 3D Printing Nano Conductive Multi-Walled Carbon Nanotube Scaffolds for Nerve Regeneration. J. Neural Eng. 2018, 15 (1), 016018. https://doi.org/10.1088/17412552/aa95a5.

(81) Shrestha, S.; Shrestha, B. K.; Lee, J.; Joong, O. K.; Kim, B. S.; Park, C. H.; Kim, C. S. A Conducting Neural Interface of Polyurethane/Silk-Functionalized Multiwall Carbon Nanotubes with Enhanced Mechanical Strength for Neuroregeneration. Mater. Sci. Eng. C 2019, 102, 511-523. https://doi.org/10.1016/j.msec.2019.04.053.

(82) Wang, J.; Tian, L.; Chen, N.; Ramakrishna, S.; Mo, X. The Cellular Response of Nerve Cells on Poly-L-Lysine Coated PLGA-MWCNTs Aligned Nanofibers under Electrical $\begin{array}{lllllll}\text { Stimulation. } & \text { Mater. } & \text { Sci. } & \text { Eng. } & \text { C 2018, } & \text { 91, } & \text { 715-726. }\end{array}$ https://doi.org/10.1016/j.msec.2018.06.025.

(83) Sun, Y.; Liu, X.; George, M. N.; Park, S.; Gaihre, B.; Terzic, A.; Lu, L. Enhanced Nerve Cell Proliferation and Differentiation on Electrically Conductive Scaffolds Embedded with Graphene and Carbon Nanotubes. J. Biomed. Mater. Res. - Part A 2020, 109, 193- 
206. https://doi.org/10.1002/jbm.a.37016.

(84) Shao, H.; Li, T.; Zhu, R.; Xu, X.; Yu, J.; Chen, S.; Song, L.; Ramakrishna, S.; Lei, Z.; Ruan, Y.; He, L. Carbon Nanotube Multilayered Nanocomposites as Multifunctional Substrates for Actuating Neuronal Differentiation and Functions of Neural Stem Cells. Biomaterials 2018, 175, 93-109. https://doi.org/10.1016/j.biomaterials.2018.05.028.

(85) Royo-Gascon, N.; Wininger, M.; Scheinbeim, J. I.; Firestein, B. L.; Craelius, W. Piezoelectric Substrates Promote Neurite Growth in Rat Spinal Cord Neurons. Ann. Biomed. Eng. 2013, 41 (1), 112-122. https://doi.org/10.1007/s10439-012-0628-y.

(86) Lee, Y. S.; Arinzeh, T. L. The Influence of Piezoelectric Scaffolds on Neural Differentiation of Human Neural Stem/Progenitor Cells. Tissue Eng. - Part A 2012, 18 (19-20), 2063-2072. https://doi.org/10.1089/ten.tea.2011.0540.

(87) Lee, Y. S.; Collins, G.; Livingston Arinzeh, T. Neurite Extension of Primary Neurons on Electrospun Piezoelectric Scaffolds. Acta Biomater. 2011, 7 (11), 3877-3886. https://doi.org/10.1016/j.actbio.2011.07.013.

(88) Genchi, G. G.; Ceseracciu, L.; Marino, A.; Labardi, M.; Marras, S.; Pignatelli, F.; Bruschini, L.; Mattoli, V.; Ciofani, G. P(VDF-TrFE)/BaTiO3 Nanoparticle Composite Films Mediate Piezoelectric Stimulation and Promote Differentiation of SH-SY5Y Neuroblastoma Cells. Adv. Healthc. Mater. 2016, 5 (14), 1808-1820. https://doi.org/10.1002/adhm.201600245.

(89) Hoop, M.; Chen, X. Z.; Ferrari, A.; Mushtaq, F.; Ghazaryan, G.; Tervoort, T.; Poulikakos, D.; Nelson, B.; Pané, S. Ultrasound-Mediated Piezoelectric Differentiation of Neuron-like 
PC12 Cells on PVDF Membranes. Sci. Rep. 2017, 7 (1), 4028. https://doi.org/10.1038/s41598-017-03992-3.

(90) Yu, Y.; Lü, X.; Ding, F. Influence of Poly(L-Lactic Acid) Aligned Nanofibers on PC12 Differentiation. J. Biomed. Nanotechnol. 2015, $11 \quad$ (5), 816-827. https://doi.org/10.1166/jbn.2015.1973.

(91) Yu, Y.; Meng, D.; Man, L.; Wang, X. The Interactions between Aligned Poly(L-Lactic Acid) Nanofibers and SH-SY5Y Cells In Vitro. J. Nanosci. Nanotechnol. 2016, 16 (6), 6407-6413. https://doi.org/10.1166/jnn.2016.10883.

(92) Wang, H. B.; Mullins, M. E.; Cregg, J. M.; Hurtado, A.; Oudega, M.; Trombley, M. T.; Gilbert, R. J. Creation of Highly Aligned Electrospun Poly-L-Lactic Acid Fibers for Nerve Regeneration Applications. J. Neural Eng. 2009, $6 \quad$ (1), 016001. https://doi.org/10.1088/1741-2560/6/1/016001.

(93) Wang, H. B.; Mullins, M. E.; Cregg, J. M.; McCarthy, C. W.; Gilbert, R. J. Varying the Diameter of Aligned Electrospun Fibers Alters Neurite Outgrowth and Schwann Cell Migration. Acta Biomater. 2010, $6 \quad$ (8), 2970-2978. https://doi.org/10.1016/j.actbio.2010.02.020.

(94) Lin, C.; Liu, C.; Zhang, L.; Huang, Z.; Zhao, P.; Chen, R.; Pang, M.; Chen, Z.; He, L.; Luo, C.; Rong, L.; Liu, B. Interaction of IPSC-Derived Neural Stem Cells on Poly(LLactic Acid) Nanofibrous Scaffolds for Possible Use in Neural Tissue Engineering. Int. J. Mol. Med. 2018, 41 (2), 697-708. https://doi.org/10.3892/ijmm.2017.3299.

(95) Zhang, K.; Zheng, H.; Liang, S.; Gao, C. Aligned PLLA Nanofibrous Scaffolds Coated 
with Graphene Oxide for Promoting Neural Cell Growth. Acta Biomater. 2016, 37, 131142. https://doi.org/10.1016/j.actbio.2016.04.008.

(96) Xu, C.; Guan, S.; Wang, S.; Gong, W.; Liu, T.; Ma, X.; Sun, C. Biodegradable and Electroconductive Poly(3,4-Ethylenedioxythiophene)/Carboxymethyl Chitosan Hydrogels for Neural Tissue Engineering. Mater. Sci. Eng. C 2018, 84, 32-43. https://doi.org/10.1016/j.msec.2017.11.032.

(97) Wu, S.; Duan, B.; Lu, A.; Wang, Y.; Ye, Q.; Zhang, L. Biocompatible Chitin/Carbon Nanotubes Composite Hydrogels as Neuronal Growth Substrates. Carbohydr. Polym. 2017, 174, 830-840. https://doi.org/10.1016/j.carbpol.2017.06.101.

(98) Liu, X.; Miller, A. L.; Park, S.; Waletzki, B. E.; Zhou, Z.; Terzic, A.; Lu, L. Functionalized Carbon Nanotube and Graphene Oxide Embedded Electrically Conductive Hydrogel Synergistically Stimulates Nerve Cell Differentiation. ACS Appl. Mater. Interfaces 2017, 9 (17), 14677-14690. https://doi.org/10.1021/acsami.7b02072.

(99) Liu, X.; Miller, A. L.; Park, S.; Waletzki, B. E.; Terzic, A.; Yaszemski, M. J.; Lu, L. Covalent Crosslinking of Graphene Oxide and Carbon Nanotube into Hydrogels Enhances Nerve Cell Responses. J. Mater. Chem. B 2016, 4 (43), 6930-6941. https://doi.org/10.1039/c6tb01722c.

(100) Liu, X.; Kim, J. C.; Miller, A. L.; Waletzki, B. E.; Lu, L. Electrically Conductive Nanocomposite Hydrogels Embedded with Functionalized Carbon Nanotubes for Spinal Cord Injury. New J. Chem. 2018, $42 \quad$ (21), 17671-17681. https://doi.org/10.1039/C8NJ03038C. 
(101) Homaeigohar, S.; Tsai, T. Y.; Young, T. H.; Yang, H. J.; Ji, Y. R. An Electroactive Alginate Hydrogel Nanocomposite Reinforced by Functionalized Graphite Nanofilaments for Neural Tissue Engineering. Carbohydr. Polym. 2019, 224, 115112. https://doi.org/10.1016/j.carbpol.2019.115112.

(102) Xu, B.; Bai, T.; Sinclair, A.; Wang, W.; Wu, Q.; Gao, F.; Jia, H.; Jiang, S.; Liu, W. Directed Neural Stem Cell Differentiation on Polyaniline-Coated High Strength Hydrogels. Mater. Today Chem. 2016, 1-2, 15-22. https://doi.org/10.1016/j.mtchem.2016.10.002.

(103) Wang, S.; Guan, S.; Xu, J.; Li, W.; Ge, D.; Sun, C.; Liu, T.; Ma, X. Neural Stem Cell Proliferation and Differentiation in the Conductive PEDOT-HA/Cs/Gel Scaffold for Neural Tissue Engineering. Biomater. Sci. 2017, 5 (10), 2024-2034. https://doi.org/10.1039/c7bm00633k.

(104) Wang, S.; Guan, S.; Li, W.; Ge, D.; Xu, J.; Sun, C.; Liu, T.; Ma, X. 3D Culture of Neural Stem Cells within Conductive PEDOT Layer-Assembled Chitosan/Gelatin Scaffolds for Neural Tissue Engineering. Mater. Sci. Eng. C 2018, 93, 890-901. https://doi.org/10.1016/j.msec.2018.08.054.

(105) Shin, J.; Choi, E. J.; Cho, J. H.; Cho, A. N.; Jin, Y.; Yang, K.; Song, C.; Cho, S. W. Three-Dimensional Electroconductive Hyaluronic Acid Hydrogels Incorporated with Carbon Nanotubes and Polypyrrole by Catechol-Mediated Dispersion Enhance Neurogenesis of Human Neural Stem Cells. Biomacromolecules 2017, 18 (10), 30603072. https://doi.org/10.1021/acs.biomac.7b00568.

(106) Heo, D. N.; Lee, S. J.; Timsina, R.; Qiu, X.; Castro, N. J.; Zhang, L. G. Development of 
3D Printable Conductive Hydrogel with Crystallized PEDOT:PSS for Neural Tissue

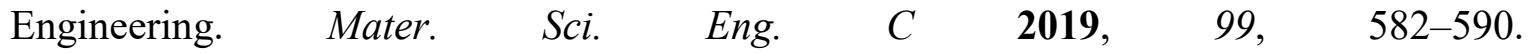
https://doi.org/10.1016/j.msec.2019.02.008.

(107) Li, N.; Zhang, Q.; Gao, S.; Song, Q.; Huang, R.; Wang, L.; Liu, L.; Dai, J.; Tang, M.; Cheng, G. Three-Dimensional Graphene Foam as a Biocompatible and Conductive Scaffold for Neural Stem Cells. Sci. Rep. 2013, 3, 1604. https://doi.org/10.1038/srep01604.

(108) Tang, X.; Thankappan, S. K.; Lee, P.; Fard, S. E.; Harmon, M. D.; Tran, K.; Yu, X. Polymeric Biomaterials in Tissue Engineering and Regenerative Medicine. In Natural and Synthetic Biomedical Polymers; 2014; pp 351-371. https://doi.org/10.1016/B978-0-12396983-5.00022-3.

(109) Chen, C.; Bai, X.; Ding, Y.; Lee, I. S. Electrical Stimulation as a Novel Tool for Regulating Cell Behavior in Tissue Engineering. Biomater. Res. 2019, 23 (1), 1-12. https://doi.org/10.1186/s40824-019-0176-8.

(110) Vaudry, D.; Stork, P. J. S.; Lazarovici, P.; Eiden, L. E. Signaling Pathways for PC12 Cell Differentiation: Making the Right Connections. Science. Science May 31, 2002, pp 16481649. https://doi.org/10.1126/science.1071552.

(111) Matsumoto, K.; Sato, C.; Naka, Y.; Whitby, R.; Shimizu, N. Stimulation of Neuronal Neurite Outgrowth Using Functionalized Carbon Nanotubes. Nanotechnology 2010, 21 (11), 115101. https://doi.org/10.1088/0957-4484/21/11/115101.

(112) Matsumoto, K.; Shimizu, N. Activation of the Phospholipase C Signaling Pathway in 
Nerve Growth Factor-Treated Neurons by Carbon Nanotubes. Biomaterials 2013, 34 (24), 5988-5994. https://doi.org/10.1016/j.biomaterials.2013.04.038.

(113) Corredor, R. G.; Goldberg, J. L. Electrical Activity Enhances Neuronal Survival and Regeneration. J. Neural Eng. 2009, 6 (5), 055001. https://doi.org/10.1088/1741$2560 / 6 / 5 / 055001$.

(114) Chen, C.; Bai, X.; Ding, Y.; Lee, I. S. Electrical Stimulation as a Novel Tool for Regulating Cell Behavior in Tissue Engineering. Biomaterials Research. BioMed Central Ltd. December 5, 2019, pp 1-12. https://doi.org/10.1186/s40824-019-0176-8.

(115) Silva, N. A.; Sousa, N.; Reis, R. L.; Salgado, A. J. From Basics to Clinical: A Comprehensive Review on Spinal Cord Injury. Progress in Neurobiology. Elsevier Ltd March 1, 2014, pp 25-57. https://doi.org/10.1016/j.pneurobio.2013.11.002.

(116) Walter, J.; Zweckberger, K. Traumatic Injuries of the Central Nervous System. Anasthesiol. Intensivmed. Notfallmedizin Schmerztherapie 2018, 53 (10), 668-681. https://doi.org/10.1055/s-0043-118969.

(117) Shoichet, M. S.; Tate, C. C.; Douglas Baumann, M.; LaPlaca, M. C. Strategies for Regeneration and Repair in the Injured Central Nervous System. In Indwelling Neural Implants: Strategies for Contending with the in Vivo Environment; CRC Press, 2007; pp 221-244. https://doi.org/10.1201/9781420009309.ch8.

(118) Ahuja, C. S.; Wilson, J. R.; Nori, S.; Kotter, M. R. N.; Druschel, C.; Curt, A.; Fehlings, M. G. Traumatic Spinal Cord Injury. Nat. Rev. Dis. Prim. 2017, 3, 17018. https://doi.org/10.1038/nrdp.2017.18. 
(119) Hutson, T. H.; Di Giovanni, S. The Translational Landscape in Spinal Cord Injury: Focus on Neuroplasticity and Regeneration. Nature Reviews Neurology. Nature Research December 1, 2019, pp 732-745. https://doi.org/10.1038/s41582-019-0280-3.

(120) Varma, A. K.; Das, A.; Wallace, G.; Barry, J.; Vertegel, A. A.; Ray, S. K.; Banik, N. L. Spinal Cord Injury: A Review of Current Therapy, Future Treatments, and Basic Science Frontiers. Neurochemical Research. Springer New York LLC 2013, pp 895-905. https://doi.org/10.1007/s11064-013-0991-6.

(121) Vigani, B.; Rossi, S.; Sandri, G.; Bonferoni, M. C.; Ferrari, F. Design and Criteria of Electrospun Fibrous Scaffolds for the Treatment of Spinal Cord Injury. Neural Regen. Res. 2017, 12 (11), 1786-1790. https://doi.org/10.4103/1673-5374.219029.

(122) Zamani, F.; Amani-Tehran, M.; Zaminy, A.; Shokrgozar, M. A. Conductive 3D Structure Nanofibrous Scaffolds for Spinal Cord Regeneration. Fibers Polym. 2017, 18 (10), 1874 1881. https://doi.org/10.1007/s12221-017-7349-7.

(123) Yang, B.; Zhang, F.; Cheng, F.; Ying, L.; Wang, C.; Shi, K.; Wang, J.; Xia, K.; Gong, Z.; Huang, X.; Yu, C.; Li, F.; Liang, C.; Chen, Q. Strategies and Prospects of Effective Neural Circuits Reconstruction after Spinal Cord Injury. Cell Death and Disease. Springer Nature June 1, 2020, pp 1-14. https://doi.org/10.1038/s41419-020-2620-z.

(124) Zhang, S.; Wang, X. J.; Li, W. S.; Xu, X. L.; Hu, J. B.; Kang, X. Q.; Qi, J.; Ying, X. Y.; You, J.; Du, Y. Z. Polycaprolactone/Polysialic Acid Hybrid, Multifunctional Nanofiber Scaffolds for Treatment of Spinal Cord Injury. Acta Biomater. 2018, 77, 15-27. https://doi.org/10.1016/j.actbio.2018.06.038. 
(125) Pan, S.; Qi, Z.; Li, Q.; Ma, Y.; Fu, C.; Zheng, S.; Kong, W.; Liu, Q.; Yang, X. Graphene Oxide-PLGA Hybrid Nanofibres for the Local Delivery of IGF-1 and BDNF in Spinal Cord Repair. Artif. Cells, Nanomedicine, Biotechnol. 2019, 47 (1), 650-663. https://doi.org/10.1080/21691401.2019.1575843.

(126) López-Dolado, E.; González-Mayorga, A.; Gutiérrez, M. C.; Serrano, M. C. Immunomodulatory and Angiogenic Responses Induced by Graphene Oxide Scaffolds in Chronic Spinal Hemisected Rats. Biomaterials 2016, 99, 72-81. https://doi.org/10.1016/j.biomaterials.2016.05.012.

(127) López-Dolado, E.; González-Mayorga, A.; Portolés, M. T.; Feito, M. J.; Ferrer, M. L.; del Monte, F.; Gutiérrez, M. C.; Serrano, M. C. Subacute Tissue Response to 3D Graphene Oxide Scaffolds Implanted in the Injured Rat Spinal Cord. Adv. Healthc. Mater. 2015, 4 (12), 1861-1868. https://doi.org/10.1002/adhm.201500333.

(128) Liu, C.; Huang, Y.; Pang, M.; Yang, Y.; Li, S.; Liu, L.; Shu, T.; Zhou, W.; Wang, X.; Rong, L.; Liu, B. Tissue-Engineered Regeneration of Completely Transected Spinal Cord Using Induced Neural Stem Cells and Gelatin-Electrospun Poly (Lactide-CoGlycolide)/Polyethylene Glycol Scaffolds. PLoS One 2015, 10 (3), e0117709. https://doi.org/10.1371/journal.pone.0117709.

(129) Zhou, X.; Shi, G.; Fan, B.; Cheng, X.; Zhang, X.; Wang, X.; Liu, S.; Hao, Y.; Wei, Z.; Wang, L.; Feng, S. Polycaprolactone Electrospun Fiber Scaffold Loaded with IPSCsNSCs and ASCs as a Novel Tissue Engineering Scaffold for the Treatment of Spinal Cord Injury. Int. J. Nanomedicine 2018, 13, 6265-6277. https://doi.org/10.2147/IJN.S175914.

(130) Wu, S.; Chen, M. S.; Maurel, P.; Lee, Y. S.; Bunge, M. B.; Arinzeh, T. L. Aligned Fibrous 
PVDF-TrFE Scaffolds with Schwann Cells Support Neurite Extension and Myelination in Vitro. J. Neural Eng. 2018, 15 (5), 056010. https://doi.org/10.1088/1741-2552/aac77f.

(131) Sun, X.; Bai, Y.; Zhai, H.; Liu, S.; Zhang, C.; Xu, Y.; Zou, J.; Wang, T.; Chen, S.; Zhu, Q.; Liu, X.; Mao, H.; Quan, D. Devising Micro/Nano-Architectures in Multi-Channel Nerve Conduits towards a pro-Regenerative Matrix for the Repair of Spinal Cord Injury. Acta Biomater. 2019, 86, 194-206. https://doi.org/10.1016/j.actbio.2018.12.032.

(132) Zhou, L.; Fan, L.; Yi, X.; Zhou, Z.; Liu, C.; Fu, R.; Dai, C.; Wang, Z.; Chen, X.; Yu, P.; Chen, D.; Tan, G.; Wang, Q.; Ning, C. Soft Conducting Polymer Hydrogels Cross-Linked and Doped by Tannic Acid for Spinal Cord Injury Repair. ACS Nano 2018, 12 (11), 10957-10967. https://doi.org/10.1021/acsnano.8b04609.

(133) Ashammakhi, N.; Kim, H. J.; Ehsanipour, A.; Bierman, R. D.; Kaarela, O.; Xue, C.; Khademhosseini, A.; Seidlits, S. K. Regenerative Therapies for Spinal Cord Injury. Tissue Eng. - Part B Rev. 2019, 25 (6), 471-491. https://doi.org/10.1089/ten.teb.2019.0182.

(134) Ludwig, P. E.; Thankam, F. G.; Patil, A. A.; Chamczuk, A. J.; Agrawal, D. K. Brain Injury and Neural Stem Cells. Neural Regeneration Research. Wolters Kluwer Medknow Publications January 1, 2018, pp 7-18. https://doi.org/10.4103/1673-5374.224361.

(135) Gan, L.; Cookson, M. R.; Petrucelli, L.; La Spada, A. R. Converging Pathways in Neurodegeneration, from Genetics to Mechanisms. Nature Neuroscience. Nature Publishing Group October 1, 2018, pp 1300-1309. https://doi.org/10.1038/s41593-018$0237-7$.

(136) Bordoni, M.; Scarian, E.; Rey, F.; Gagliardi, S.; Carelli, S.; Pansarasa, O.; Cereda, C. 
Biomaterials in Neurodegenerative Disorders: A Promising Therapeutic Approach. Int. J. Mol. Sci. 2020, 21 (9), 3243. https://doi.org/10.3390/ijms21093243.

(137) Marei, H. E.; Elnegiry, A. A.; Zaghloul, A.; Althani, A.; Afifi, N.; Abd-Elmaksoud, A.; Farag, A.; Lashen, S.; Rezk, S.; Shouman, Z.; Cenciarelli, C.; Hasan, A. Nanotubes Impregnated Human Olfactory Bulb Neural Stem Cells Promote Neuronal Differentiation in Trimethyltin-Induced Neurodegeneration Rat Model. J. Cell. Physiol. 2017, 232 (12), 3586-3597. https://doi.org/10.1002/jcp.25826.

(138) Poewe, W.; Seppi, K.; Tanner, C. M.; Halliday, G. M.; Brundin, P.; Volkmann, J.; Schrag, A. E.; Lang, A. E. Parkinson Disease. Nat. Rev. Dis. Prim. 2017, 3, 1-21. https://doi.org/10.1038/nrdp.2017.13.

(139) Draoui, A.; El Hiba, O.; Aimrane, A.; El Khiat, A.; Gamrani, H. Parkinson's Disease: From Bench to Bedside. Revue Neurologique. Elsevier Masson SAS 2020. https://doi.org/10.1016/j.neurol.2019.11.002.

(140) Wang, T. Y.; Bruggeman, K. F.; Kauhausen, J. A.; Rodriguez, A. L.; Nisbet, D. R.; Parish, C. L. Functionalized Composite Scaffolds Improve the Engraftment of Transplanted Dopaminergic Progenitors in a Mouse Model of Parkinson's Disease. Biomaterials 2016, 74, 89-98. https://doi.org/10.1016/j.biomaterials.2015.09.039.

(141) Ucar, B.; Humpel, C. Therapeutic Efficacy of Glial Cell-Derived Neurotrophic Factor Loaded Collagen Scaffolds in Ex Vivo Organotypic Brain Slice Parkinson's Disease $\begin{array}{llllll}\text { Models. } & \text { Brain } & \text { Res. } & \text { Bull. } & \text { 2019, } & \text { 149, }\end{array}$ https://doi.org/10.1016/j.brainresbull.2019.04.012. 
(142) Benjamin, E. J.; Virani, S. S.; Callaway, C. W.; Chamberlain, A. M.; Chang, A. R.; Cheng, S.; Chiuve, S. E.; Cushman, M.; Delling, F. N.; Deo, R.; De Ferranti, S. D.; Ferguson, J. F.; Fornage, M.; Gillespie, C.; Isasi, C. R.; Jiménez, M. C.; Jordan, L. C.; Judd, S. E.; Lackland, D.; Lichtman, J. H.; Lisabeth, L.; Liu, S.; Longenecker, C. T.; Lutsey, P. L.; MacKey, J. S.; Matchar, D. B.; Matsushita, K.; Mussolino, M. E.; Nasir, K.; O’Flaherty, M.; Palaniappan, L. P.; Pandey, A.; Pandey, D. K.; Reeves, M. J.; Ritchey, M. D.; Rodriguez, C. J.; Roth, G. A.; Rosamond, W. D.; Sampson, U. K. A.; Satou, G. M.; Shah, S. H.; Spartano, N. L.; Tirschwell, D. L.; Tsao, C. W.; Voeks, J. H.; Willey, J. Z.; Wilkins, J. T.; Wu, J. H. Y.; Alger, H. M.; Wong, S. S.; Muntner, P. Heart Disease and Stroke Statistics - 2018 Update: A Report from the American Heart Association. Circulation 2018, 137 (12), E67-E492. https://doi.org/10.1161/CIR.0000000000000558.

(143) Bolan, F.; Louca, I.; Heal, C.; Cunningham, C. J. The Potential of Biomaterial-Based Approaches as Therapies for Ischemic Stroke: A Systematic Review and Meta-Analysis of Pre-Clinical Studies. Front. Neurol. 2019, $10 \quad$ (AUG), 924. https://doi.org/10.3389/fneur.2019.00924.

(144) Oh, B.; George, P. Conductive Polymers to Modulate the Post-Stroke Neural Environment. Brain Research Bulletin. Elsevier Inc. May 1, 2019, pp 10-17. https://doi.org/10.1016/j.brainresbull.2019.02.015.

(145) George, P. M.; Bliss, T. M.; Hua, T.; Lee, A.; Oh, B.; Levinson, A.; Mehta, S.; Sun, G.; Steinberg, G. K. Electrical Preconditioning of Stem Cells with a Conductive Polymer Scaffold Enhances Stroke Recovery. Biomaterials 2017, 142, 31-40. https://doi.org/10.1016/j.biomaterials.2017.07.020. 
(146) Yan, F.; Yue, W.; Zhang, Y. L.; Mao, G. C.; Gao, K.; Zuo, Z. X.; Zhang, Y. J.; Lu, H. Chitosan-Collagen Porous Scaffold and Bone Marrow Mesenchymal Stem Cell Transplantation for Ischemic Stroke. Neural Regen. Res. 2015, 10 (9), 1421-1426. https://doi.org/10.4103/1673-5374.163466.

(147) Moon, S. U.; Kim, J.; Bokara, K. K.; Kim, J. Y.; Khang, D.; Webster, T. J.; Lee, J. E. Carbon Nanotubes Impregnated with Subventricular Zone Neural Progenitor Cells Promotes Recovery from Stroke. Int. J. Nanomedicine 2012, 7, 2751-2765. https://doi.org/10.2147/IJN.S30273.

(148) Corrigan, J. D;; Harrinson-Felix, C.; Haarbauer-Krupa, J. Epidemiology of Traumatic Brain Injury. In Textbook of Traumatic Brain Injury; Silver, J. M., McAllister, T. W., Arciniegas, D. B., Eds.; American Psychiatric Association: Washington DC, 2019; pp 324.

(149) Ng, S. Y.; Lee, A. Y. W. Traumatic Brain Injuries: Pathophysiology and Potential Therapeutic Targets. Frontiers in Cellular Neuroscience. Frontiers Media S.A. November 27, 2019, p 528. https://doi.org/10.3389/fncel.2019.00528.

(150) Chen, L.; Yan, C.; Zheng, Z. Functional Polymer Surfaces for Controlling Cell Behaviors. Materials Today. Elsevier B.V. January 1, 2018, pp 38-59. https://doi.org/10.1016/j.mattod.2017.07.002.

(151) Nga, V. D. W.; Lim, J.; Choy, D. K. S.; Nyein, M. A.; Lu, J.; Chou, N.; Yeo, T. T.; Teoh, S. H. Effects of Polycaprolactone-Based Scaffolds on the Blood-Brain Barrier and Cerebral Inflammation. Tissue Eng. - Part A 2015, 21 (3-4), 647-653. https://doi.org/10.1089/ten.tea.2013.0779. 
(152) Choy, D. K. S.; Nga, V. D. W.; Lim, J.; Lu, J.; Chou, N.; Yeo, T. T.; Teoh, S. H. Brain Tissue Interaction with Three-Dimensional, Honeycomb Polycaprolactone-Based Scaffolds Designed for Cranial Reconstruction Following Traumatic Brain Injury. In Tissue Engineering - Part A; Mary Ann Liebert Inc., 2013; Vol. 19, pp 2382-2389. https://doi.org/10.1089/ten.tea.2012.0733.

(153) Zhou, K.; Motamed, S.; Thouas, G. A.; Bernard, C. C.; Li, D.; Parkington, H. C.; Coleman, H. A.; Finkelstein, D. I.; Forsythe, J. S. Graphene Functionalized Scaffolds Reduce the Inflammatory Response and Supports Endogenous Neuroblast Migration When Implanted in the Adult Brain. PLoS One 2016, 11 (3), e0151589. https://doi.org/10.1371/journal.pone.0151589.

(154) Hess, L. H.; Becker-Freyseng, C.; Wismer, M. S.; Blaschke, B. M.; Lottner, M.; Rolf, F.; Seifert, M.; Garrido, J. A. Electrical Coupling between Cells and Graphene Transistors. Small 2015, 11 (14), 1703-1710. https://doi.org/10.1002/smll.201402225.

(155) Guo, R.; Zhang, S.; Xiao, M.; Qian, F.; He, Z.; Li, D.; Zhang, X.; Li, H.; Yang, X.; Wang, M.; Chai, R.; Tang, M. Accelerating Bioelectric Functional Development of Neural Stem Cells by Graphene Coupling: Implications for Neural Interfacing with Conductive Materials. $\quad$ Biomaterials $\quad$ 2016, 106, 193-204. https://doi.org/10.1016/j.biomaterials.2016.08.019.

(156) Rivet, C. J.; Zhou, K.; Gilbert, R. J.; Finkelstein, D. I.; Forsythe, J. S. Cell Infiltration into a 3D Electrospun Fiber and Hydrogel Hybrid Scaffold Implanted in the Brain. Biomatter 2015, 5 (1), e1005527. https://doi.org/10.1080/21592535.2015.1005527.

(157) Pradhan, K.; Das, G.; Khan, J.; Gupta, V.; Barman, S.; Adak, A.; Ghosh, S. Neuro- 
Regenerative Choline-Functionalized Injectable Graphene Oxide Hydrogel Repairs Focal Brain Injury. ACS Chem. Neurosci. 2019, 10 (3), 1535-1543. https://doi.org/10.1021/acschemneuro.8b00514.

(158) Tan, K.; Wang, X.; Zhang, J.; Zhuang, Z.; Dong, T. Effect of Chitosan Porous Scaffolds Combined with Bone Marrow Mesenchymal Stem Cells in Repair of Neurological Deficit after Traumatic Brain Injury in Rats. Zhongguo Xiu Fu Chong Jian Wai Ke Za Zhi 2018, 32 (6), 745-752. https://doi.org/10.7507/1002-1892.201712047.

(159) Yan, F.; Li, M.; Zhang, H. Q.; Li, G. L.; Hua, Y.; Shen, Y.; Ji, X. M.; Wu, C. J.; An, H.; Ren, M. Collagen-Chitosan Scaffold Impregnated with Bone Marrow Mesenchymal Stem Cells for Treatment of Traumatic Brain Injury. Neural Regen. Res. 2019, 14 (10), 17801786. https://doi.org/10.4103/1673-5374.257533.

(160) Ribeiro, C.; Sencadas, V.; Correia, D. M.; Lanceros-Méndez, S. Piezoelectric Polymers as Biomaterials for Tissue Engineering Applications. Colloids Surfaces B Biointerfaces 2015, 136, 46-55. https://doi.org/10.1016/j.colsurfb.2015.08.043.

(161) Khan, F.; Tanaka, M. Designing Smart Biomaterials for Tissue Engineering. Int. J. Mol. Sci. 2018, 19 (1), 17. https://doi.org/10.3390/ijms19010017. 


\section{FOR TABLE OF CONTENTS ONLY}

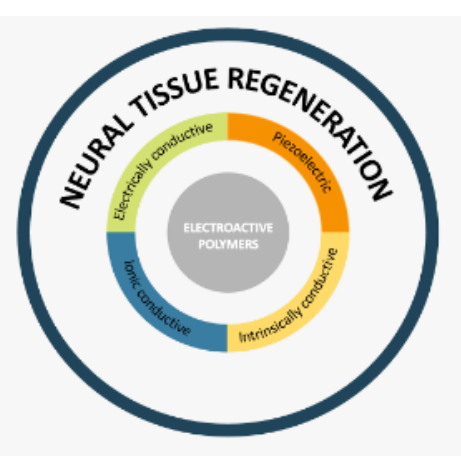

